\title{
Analisis Kapasitas Drainase Sinrijala Terhadap Operasi dan Pemeliharaan
}

\author{
Sugiarto Badaruddin ${ }^{1, a}$, Andi Nahrisa ${ }^{2}$, Nurhikmah Alam ${ }^{3}$, Dr.Ir. Basyar Bustan, M.T. ${ }^{4}$, \\ Hasdaryatmin Djufri, S.T., MT. ${ }^{5}$ \\ 1,2,3,4,5 Jurusan Teknik Sipil Program Studi D4 Jasa Konstruksi Politeknik Negeri Ujung Pandang \\ Makassar, Sulawesi Selatan, Indonesia Jalan Perintis Kemerdekaan KM 10 Makassar 90425 Indonesia \\ ${ }^{\text {a }}$ sugibadaruddin@poliupg.ac.id
}

\begin{abstract}
Abstrak-Drainase Sinrijala merupakan salah satu jaringan sistem drainase perkotaan kota Makassar yang memiliki banyak permasalahaan. Permasalahan-permasalahan tersebut diantaranya sedimentasi yang menumpuk pada dasar saluran, tumpukan sampah rumah tangga dan limbah industri, permasalahan interkoneksi saluran sekunder dan tersier ke saluran primer, serta kondisi eksisting struktur bangunan yang mengalami kerusakan.Dari permasalahan tersebut mengakibatkan terjadinya genangan di beberapa titik pada daerah sekitar drainase.Permasalahan sistem drainase sangat erat kaitannya dengan operasi dan pemeliharaan.Sehingga tujuan dari penelitian ini yaitu untuk menganalisis kapasitas Drainase Sinrijala dan mencari solusi alternative dalam melakukan operasi dan pemeliharaan untuk peningkatan kapasitas Drainase Sinrijala.Dalam penelitian ini dilakukan dua analisis yaitu analisis kondisi saluran dan analisis kinerja operasi dan pemeliharaan saluran. Analisis terkait kondisi saluran dengan melakukan inventarisasi kondisi eksisting saluran dan menghitung debit penampang saluran $(Q s)$ dan debit rencana $(Q t)$ untuk mendapatkan nilai kapasitas saluran. Analisis kapasitas penampang dilakukan dengan menggunakan aplikasi HEC-RAS versi 4.1.0. Selain itu, melakukan penilaian terhadap kinerja operasi dan pemeliharaan dengan penyebaran kuesioner pada instansi terkait yang berwenang dalam pengelolaan drainase perkotaan kota Makassar. Penilaian responden menggunakan metode skala likert dan menganalisisnya dengan menggunakan aplikasi IBM SPSS versi 26. Berdasarkan hasil penelitian yang dilakukan diperoleh debit rencana yang dihasilkan pada drainase Sinrijala adalah $Q 2=8,798 \mathrm{~m}^{3} /$ detik dan $Q 5=10,304 \mathrm{~m}^{3} /$ detik. Dari hasil simulasi eksisting dengan $Q 2$ tahun diperoleh P.16, P.17, P.18, P.19, P.20, P.21, P.22, P.23, P.24, P.25, P.26, P.27, P.28, P.29, P.30, P.32, P.33, dan P.34 tidak memenuhi syarat kapasitas saluran, sementara untuk $Q 5$ tahun tidak memenuhi syarat kapasitas saluran pada P.16, P.17, P.18, P.19, P.20, P.21, P.22, P.23, P.24, P.25, P.26, P.27, P.28, P.28, P.29, P.30 P.32, P.33, dan P.34. Sementara untuk penilaian kinerja, variabel Fisik Bangunan (X4) merupakan faktor yang berpengaruh dominan dalam kinerja peningkatan kapasitas Drainase Sinrijala, upaya dalam mengatasi permasalahan banjir dan genangan adalah melakukan normalisasi berupa pengerukan, penambahan tanggul dan perbaikan dinding saluran yang mengalami kerusakan berat
\end{abstract}

menjadi prioritas utama untuk meningkatkan fisik bangunan drainase Sinrijala.

Kata kunci :Drainase Sinrijala, Kapasitas, Operasi dan Pemeliharaan, HEC-RAS, SPSS

\section{Pendahuluan}

Kota Makassar adalah salah satu kota metropolitan di Indonesia dengan berbagai aktivitas. Dengan kesibukan tersebut tentu harus didukung dengan insfrastruktur perkotaan yang baik termasuk pada sistem drainase perkotaanya. Nyatanya, sistem drainase Kota Makassar belum terlalu memadai di segala penjuru kota. Hal tersebut yang mengakibatkan adanya dampak banjir dan kondisi drainase yang tidak sehat.

Drainase Sinrijala merupakan salah satu jaringan sistem drainase perkotaan kota Makassar yang memiliki banyak permasalahaan. Permasalahan-permasalahan tersebut diantaranya sedimentasi yang menumpuk pada dasar saluran, tumpukan sampah rumah tangga dan limbah industri, permasalahan interkoneksi saluran sekunder dan tersier ke saluran primer, serta kondisi eksisting struktur bangunan yang mengalami kerusakan.

Menurut penuturan masyarakat sekitar, jika terjadi hujan dengan intensitas yang tinggi maka akan terjadi genangan dan banjir di pemukiman tersebut. Daerah tersebut juga merupakan daerah padat penduduk sehingga tidak adanya ruang untuk resapan air hujan. Tergenangnya daerah sekitar saluran di sepanjang drainase disebabkan oleh beberapa faktor, salah satunya yakni air yang mengalir pada saluran melebihi kapasitas tampungan saluran yang tidak mampu mengendalikan debit banjir maksimum sehingga air meluap dan 
akhirnya menimbulkan genangan di daerah sekitarnya. Penyebab dari berkurangnya kapasitas saluran dapat diakibatkan dari kondisi eksisting saluran yang sudah tidak memadai.

Drainase Sinrijala kurang mendapat perhatian mengenai pemeliharaan drainase, sehingga tidak bisa dipungkiri bahwa permasalahan yang datang pada lingkungan sekitar drainase tersebut berkaitan terhadap kurangnya operasi dan pemeliharaan sistem drainase. Pelaksanaan operasi dan pemeliharaan juga harus selaras dengan permasalahan yang ada pada drainase tersebut. Oleh karena itu perlu dilakukan sebuah kajian untuk menganalisis permasalahan yang ada pada Drainase Sinrijala.

Berdasarkan pada permasalahan tersebut, penulis mengangkatnya sebagai penelitian skripsi tentang "Analisis Kapasitas Drainase Sinrijala Terhadap Operasi dan Pemeliharaan" yang diharapkan dapat menjadi referensi bagi pihak-pihak terkait dalam menanggulangi permalahan-permasalahan yang ada.

Dari latar belakang yang telah disampaikan, rumusan masalah dari penelitian ini yaitu :

1) Bagaimana kapasitas eksisting Drainase Sinrijala Kota Makassar?

2) Bagaimana solusi yang paling tepat dalam pelaksanaan operasi dan pemeliharaan dalam peningkatan kapasitas pada Drainase Sinrijala Kota Makassar?

Adapun tujuan penelitian ini yaitu :

1) Menganalisis kapasitas dan dimensi saluran eksisting pada Drainase Sinrijala Kota Makassar.

2) Memperoleh solusi yang tepat berdasarkan alternatif yang ada dalam melakukan operasi dan pemeliharaan untuk peningkatan kapasitas pada Drainase Sinrijala Kota Makassar.

\section{Tinjauan Pustaka}

\section{A. Pengertian Drainase}

Drainase mempunyai arti mengalirkan, menguras, membuang, atau mengalihkan air. Secara umum, drainase didefinisikan sebagai serangkaian bangunan air yang berfungsi untuk mengurangi dan/atau membuang kelebihanair dari suatu kawasan atau lahan, sehingga lahan dapat difungsikan secara optimal. Drainase juga diartikan sebagai usaha untuk mengontrol kualitas air tanah dalam kaitannya dengan sanitasi. (Dr. Ir. Suripin, M.Eng. 2004). Sedangkan pengertian drainase kota pada dasarnya telah diatur dalam SK menteri PU No. 233 tahun 1987.

\section{B. Permasalahan Drainase Perkantoran}

Banyak faktor yang mempengaruhi dan pertimbangan yang matang dalam perencanaan antara lain:

1) Peningkatan Debit

2) Penataan Lingkungan

3) Perubahan Tata Guna Lahan

4) Kapasitasi Saluran

5) Penyalahgunaan fungsi saluran

\section{Perencanaan Operasi dan Pemeliharaan Prasarana dan Prasarana Drainase}

Operasi dan pemeliharaan prasarana dan sarana drainase perkotaan merupakan bagian dari sistem drainase perkotaan. Sistem yang baik, jika tidak dibarengi dengan operasi dan pemeliharaan yang baik, maka tidak akan berfungsi dengan baik. Oleh karena itu operasi dan pemeliharaan drainase perkotaan sangat penting dalam rangka mensejahterakan masyarakat, yaitu dengan cara mengurangi atau menghilangkan genangan air atau banjir yang sangat merugikan masyarakat.

Pemeliharaan sistem drainase perkotaan mencakup bentuk pemeliharaan dan perbaikan yang dilakukan untuk menjaga tetap berfungsinya sistem drainase yang ada jenis pemeliharaan meliputi :

1) Pemeliharaan rutin adalah pekerjaan yang selalu dilakukan berulang-ulang pada waktu tertentu misalnya setiap hari, minggu, ataubulan.

2) Pemeliharaan berkala merupakan pekerjaan yang dilaksanakan pada waktu tertentu, misalnya setahun sekali atau setahun duakali.

3) Pemeliharaan khusus dapat dilakukan apabila prasarana dan sarana mengalami kerusakan yang sifatnya mendadak.

4) Rehabilitasi, dilakukan apabila prasarana dan sarana mengalami kerusakan yang menyebabkan bangunan tidakberfungsi.

\section{Kinerja Jaringan Kanal/Saluran}

Kapasitas dan kondisi fisik jaringan yang dibagi menjadi beberapa komponen, yaitu terdiri dari saluran penerima (interseptor drain), saluran pengumpul (colector drain), saluran pembawa (conveyor drain), saluran induk (main drain) dan bangunan pelengkap lainnya seperti gorong-gorong, dan bangunan pertemuan (bak control). 
Tabel Pedoman Penilaian Jaringan Salran/Kanal

\begin{tabular}{|c|c|c|c|}
\hline \multicolumn{4}{|c|}{ Badan Saluran } \\
\hline \multirow{2}{*}{ Kriteria } & \multicolumn{3}{|c|}{ Kondisi Bangunan } \\
\hline & Baik & Cukup & Rusak \\
\hline $\begin{array}{l}\text { Kapasitas } \\
\text { (Dimensi } \\
\text { penampang } \\
\text { melintang) }\end{array}$ & $\begin{array}{l}\text { Memenuhi } \\
\text { kapasitas } \\
\text { pembebanan sesuai } \\
\text { dengan } \\
\text { perencanaan dan } \\
\text { mempunyai tinggi } \\
\text { jagaan yang cukup } \\
\text { untuk mencegah air } \\
\text { melimpah. } \\
\text { Kondisi rata-rata } \\
\text { diatas } 80 \% \text { - } 100 \% \\
\end{array}$ & $\begin{array}{l}\text { Memenuhi } \\
\text { kapasitas } \\
\text { pembebanan sesuai } \\
\text { dengan } \\
\text { perencanaan dan } \\
\text { mempunyai tinggi } \\
\text { jagaan yang sesuai } \\
\text { dengan muka air } \\
\text { maksimum. } \\
\text { Kondisi rata-rata } \\
\text { diatas 50\% - } 79 \%\end{array}$ & $\begin{array}{l}\text { Tidak memenuhi } \\
\text { kapasitas } \\
\text { pembebanan sesuai } \\
\text { dengan } \\
\text { perencanaan. } \\
\text { Kondisi rata-rata } \\
\text { diatas 0\% - 49\% }\end{array}$ \\
\hline $\begin{array}{l}\text { Pengendapan } \\
\text { /Sedimen }\end{array}$ & $\begin{array}{l}\text { Tidak ada endapan } \\
\text { yang berpengaruh } \\
\text { terhadap kapasitas } \\
\text { rencana saluran. } \\
\text { Kondisi rata-rata } \\
\text { diatas } 80 \% \text { - } 100 \%\end{array}$ & $\begin{array}{l}\text { Ada endapan yang } \\
\text { berpengaruh } \\
\text { terhadap kapasitas } \\
\text { rencana saluran (< } \\
30 \%) \text {. } \\
\text { Kondisi rata-rata } \\
\text { diatas 50\% - 79\% }\end{array}$ & $\begin{array}{l}\text { Ada endapan yang } \\
\text { berpengaruh } \\
\text { terhadap kapasitas } \\
\text { rencana saluran (> } \\
30 \%) \text {. } \\
\text { Kondisi rata-rata } \\
\text { diatas 0\% - 49\% }\end{array}$ \\
\hline Kerusakan & $\begin{array}{l}\text { Profil saluran } \\
\text { keadaannya masih } \\
\text { baik/tidak ada } \\
\text { kerusakan. } \\
\text { Kondisi rata-rata } \\
\text { diatas } 80 \%-100 \%\end{array}$ & $\begin{array}{l}\text { Profil saluran } \\
\text { keadaannya ada } \\
\text { kerusakan }(<30 \%) \text {. } \\
\text { Kondisi rata-rata } \\
\text { diatas } 50 \%-79 \%\end{array}$ & $\begin{array}{l}\text { Profil saluran } \\
\text { keadaannya ada } \\
\text { kerusakan (> 30\%). } \\
\text { Kondisi rata-rata } \\
\text { diatas 0\% - 49\% }\end{array}$ \\
\hline
\end{tabular}

\section{E. Kajian dan Analisis Drainase dan Konservasi Air}

Analisis yang dilakukan meliputi hal-hal sebagai berikut :

1) Analisis kondisi eksisting, yaitu :

a) Analisis kapasitas sistem drainase eksisting, kapasitas saluran, segmen saluran, dan bangunan pendukungnya.

b) Bandingkan analisis pada point a) dengan kapasitas rencana (awal), jika kapasitas eksisting lebih besar atau sama dengan kapasitas awal, maka komponen sistem drainase yang bersangkutan masih aman, sebaliknya perlu dilakukan tindakan.

2) Analisis kebutuhan, yaitu:

a) Tentukan rencana saluran sesuai topografi dan rencana tata guna lahan dan/atau tata ruang. Dalam penataan jaringan saluran drainase diusahakan sebanyak mungkin mengikuti pola eksisting dan alur alam. Kembangkan sistem gravitasi, sistem pompa hanya dipakai kalau tidak ada alternative lain.

b) Tentukan kala ulang pada masing-masing saluran dan/atau segmen saluran sesuai dengan klarifikasi kota dan orde saluran.

c) Analisis hujan kawasan dan intensitas hujan dengan kala ulang yang diperlukan.

d) Hitung debit rencana masing-masing saluran dan/atau segmen saluran dengan metode yang sesuai, untuk sistem pompa dan/atau sistem polder perlu dihitung hidrograf banjir.

e) Analisis perbedaan antara kebutuhan (point d) dan kondisi yang ada. Apabila kapasitas saluran eksisting lebih besar atau sama dengan debit rencana, maka saluran yang ada dapat digunakan. Apabila saluran eksisting lebih kecil dari rencana maka saluran tersebut perlu ada tindakan.

f) Tindakan yang dilakukan dilakukan diarahkan untuk penurunan debit, dengan mengimplementasikan fasilitas pemanenan air hujan. Jika dengan tindakan ini kapasitas saluran masih lebih kecil dari debit yang akan terjadi, baru dilakukan peningkatan kapasitas.

3) Analisa solusi

Dari peta genangan, kemudian dibuat beberapa alternative pemecahan atau solusi dan dipilih satu alternative yang paling efisien dan efektif. Alternatif itu yang dijadikan dasar untuk perencanaan detail dan penyusunan program tahunan.

\section{F. Kriteria Perencanaan Hidrologi}

1) Analisa Curah Hujan Rata-Rata Aljabar

$$
P=\frac{P 1+P 2+P 3+\cdots+P n}{n}=\frac{\sum_{i=1}^{n} P i}{n}
$$

Dimana :

$$
\begin{aligned}
\mathrm{P} 1,, \mathrm{Pn}= & \begin{array}{c}
\text { Curah hujan yang tercatat di pos } \\
\text { penakar hujan } 1,2, \ldots, \mathrm{n}
\end{array} \\
\mathrm{N} & =\begin{array}{l}
\text { Banyaknya pos penakar hujan } \\
\end{array}
\end{aligned}
$$

2) Uji Konsistensi

$$
\begin{gathered}
S k^{* *}=\frac{S k^{*}}{D_{y}} \\
D y^{2}=\sum_{i=1}^{N} \frac{\left(Y_{i}-\bar{Y}\right)^{2}}{N}
\end{gathered}
$$

Dimana :

$$
\begin{aligned}
\mathrm{Sk}^{*}= & \text { Nilai kumulatif penyimpangannya } \\
& \text { terhadap nilai rata-rata. } \\
\mathrm{Yi} & =\text { Nilai data } \mathrm{Y} \text { ke } \mathrm{i} \\
\overline{\mathrm{Y}} & =\text { Nilai Y rata-rata } \\
\mathrm{N} & =\text { Jumlah data } \mathrm{Y} \\
\mathrm{Sk}^{* *} & =\text { Rescaled Adjusted Partial Sums } \\
& \text { (RAPS) } \\
\text { Dy } \quad & \text { Deviasi standar seri data } \mathrm{Y}
\end{aligned}
$$


Setelah nilai $\mathrm{Sk}^{* *}$ diperoleh untuk setiap $\mathrm{k}$, tentukan nilai $\mathrm{Q}$ dan $\mathrm{R}$ terhitung dengan rumus :

atau

$$
Q=\left|S k^{* *}\right| \text { maks }
$$

$$
\mathbf{R}=\mathbf{S} \mathbf{k}^{* *} \mathbf{m a k s}-\mathbf{S k}^{* *} \mathbf{m i n}
$$

Bandingkan, untuk jumlah data $(\mathrm{N})$ dan derajat kepercayaan $(\alpha)$ tertentu, nilai-nilai dibawah ini :

a) $Q$ terhitung dengan $Q_{\text {kritis }}$

b) $\mathrm{R}$ terhitung dengan $\mathrm{R}_{\text {kritis }}$

Maka seri data yang dianalisis adalah konsisten.

3) Distribusi Probabilitas

Distribusi Probabilitas Log Pearson Type III

$$
\log \mathbf{X}_{\mathbf{T}}=\overline{\log X}+K_{T} \times S \log X
$$

Dimana :

$\log X_{T}=$ Nilai logaritmis hujan rencana dengan periode ulang $\mathrm{T}$

$\overline{\log X}=$ Nilai rata-rata dari $\log \mathrm{X}=\frac{\sum_{i=1}^{n} \log X_{i}}{n}$

$S \log X=$ Deviasi Standar dari $\log X$

$S \log X=\sqrt{\frac{\sum_{i=1}^{n}\left(\log X_{i}-\overline{\log X}\right)^{2}}{n-1}}$

$\mathrm{K}_{\mathrm{T}} \quad=$ Variabel standar, besarnya bergantung koefisien kepencengan (Cs atau G),

4) Uji Distribusi Probabilitas

a. Metode Chi-Kuadrat $\left(\chi^{2}\right)$

$$
x^{2}=\sum_{i=1}^{n} \frac{\left(O_{i}-E_{i}\right)^{2}}{E_{i}}
$$

Dimana :

$$
\begin{aligned}
\chi^{2} & =\text { Parameter Chi-Kuadrat terhitung } \\
\mathrm{Ei} & =\text { Frekuensi yang diharapkan sesuai } \\
& \text { dengan pembagian kelasnya } \\
\mathrm{Oi} & =\begin{array}{l}
\text { Frekuensi yang diamati pada kelas } \\
\text { yang sama }
\end{array} \\
\mathrm{n} & =\text { Jumlah sub kelompok }
\end{aligned}
$$

b. Metode Smirnov-Kolmogorof

Dimana :

$$
\mathrm{P}(\mathrm{Xi})=\frac{n+1}{i}
$$

$\mathrm{n}=$ Jumlah data

$\mathrm{i} \quad=$ Nomor urut data (setelah diurut dari besar ke kecil atau sebaliknya)
5) Intensitas Hujan Rencana

Dimana :

$$
I=\frac{R_{24}}{24}\left(\frac{24}{t_{c}}\right)^{2 / 3}
$$

I = Intensitas curah hujan ( $\mathrm{mm} / \mathrm{jam})$

R24 = Curah hujan harian maksimum atau hujan rencana (mm)

$\mathrm{t}_{\mathrm{c}} \quad=$ waktu konsentrasi (jam)

6) Debit Banjir Rencana

$$
\mathrm{Q}=\mathbf{0 . 0 0 2 7 8} \times \mathrm{C} \times \mathrm{I} \times \mathrm{A}
$$

Dimana :

Q $=$ Debit puncak limpasan permukaan $\left(\mathrm{m}^{3} / \mathrm{det}\right)$

$\mathrm{C}=$ Angka pengaliran

A $\quad=$ Luas daerah pengaliran $\left(\mathrm{Km}^{2}\right)$

I = Intensitas curah hujan $(\mathrm{mm} / \mathrm{jam})$

7) Debit Air Kotor

Adapun besarnya kebutuhan air penduduk rata-rata adalah 150 liter/orang/hari. Sedangkan debit air kotor yang harus dibuang di dalam saluran adalah $70 \%$ dari kebutuhan air bersih sehingga besarnya air buangan adalah $($ suhardjono, 1984:39) $=150 \times 70 \%=105$ liter/orang/hari $=0,00121$ liter/dtk/orang.

$$
Q_{a k}=\frac{p n \times q}{A}
$$

Dimana :

$$
\begin{array}{ll}
\text { Qak } & =\text { Debit Air Kotor } \\
\mathrm{Pn} & =\text { Jumlah Penduduk(jiwa) } \\
\mathrm{q} & =\text { Jumlah Air Buangan (ltr/dtk/orang) } \\
\mathrm{A} & =\text { Luas Daerah }\left(\mathrm{km}^{2}\right)
\end{array}
$$

\section{G. Kriteria Perencanaan Hidrolika dengan HEC-RAS}

Tiga komponen analisis hidrolik satu dimensi, yaitu :

1) Perhitungan profil permukaan air aliran lunak (steadyflow)

2) Simulasi aliran tak lunak (unsteadyflow)

3) Perhitungan SedimentTransport

Adapun langkah-langkahnya adalah sebagai berikut :

a) Melakukan pengukuran langsung di lapangan untuk mencari nilai kecepatan aliran dan tinggi aliran di beberapa titik, sedikitnya tiga titik yaitu di hulu, hilir, dan di tengah saluran atau yang mewakili. 
b) Dari hasil pengukuran yang diperoleh maka dicari nilai debitnya.

c) Nilai debit tersebut dimasukkan ke dalam model saluran yang telah dibuat pada programHECRAS.

d) Membuat dan mengisi geometri data sungai yang ditinjau (koordinat $\mathrm{x}$, y untuk potongan memanjang, penampang melintang).

e) Koefisien Manning berdasarkan penampang sungai.

f) Memasukkan data aliran, aliran steady atau unsteady.

g) Setelah memasukkan data geometri dan data aliran, maka selanjutnya me-running simulasi.

h) Setelah pemrosesan simulasi selesai, maka HECRAS dapat menampilkan hasil simulasi tiap-tiap penampang melintang dan simulasi aliran secara keseluruhan disepanjang alur drainase.

Untuk kekasaran manning yang digunakan disesuaikan dengan kondisi Drainase Sinrijala bantaran kiri, kanan, dan dasar sungai.

Tabel Koefisien Kekasaran Manning untuk Saluran

\begin{tabular}{clc}
\hline Saluran & \multicolumn{1}{c}{ Bahan } & Koefisien Manning, $\mathrm{n}$ \\
\hline \multirow{4}{*}{ Tanah } & Lurus, baru, seragam, landai dan bersih & $0,016-0,033$ \\
\cline { 2 - 3 } & Berkelok, landau dan berumput & $0,023-0,040$ \\
\cline { 2 - 3 } & Tidak terawat dan kotor & $0,050-0,140$ \\
\cline { 2 - 3 } & Tanah berbatu, kasar dan tidak teratur & $0,035-0,045$ \\
\hline \multirow{2}{*}{ Pasangan } & Batu kosong & $0,023-0,035$ \\
\cline { 2 - 3 } & Pasangan batu belah & $0,017-0,030$ \\
\hline \multirow{2}{*}{ Beton } & Halus, sambungan baik dan rata & $0,014-0,018$ \\
\cline { 2 - 3 } & Kurang halus dan sambungan kurang & $0,018-0,030$ \\
& rata & \\
\hline
\end{tabular}

Sumber : Ir. Darmadi, MM,MT : 2016

\section{H. Software IBM SPSS Statistik Versi 26}

Statistik yang termasuk software dasar SPSS yaitu :

a) Statistik Deskriptif: Tabulasi Silang, Frekuensi, Deskripsi, Penelusuran, Statistik Deskripsi Rasio

b) Statistik Bivariat: Rata-rata, t-test, ANOVA, Korelasi (bivariat, parsial, jarak), Nonparametric tests.

c) Prediksi Hasil Numerik: Regresi Linear.

d) Prediksi untuk mengidentifikasi kelompok: Analisis Faktor, Analisis Cluster (twostep, Kmeans, hierarkis), Diskriminan.
Untuk dapat memahami cara kerja software SPSS, berikut dikemukakan cara pengujian SPSS:

1) Uji Kualitas Data

a) Uji Validitas

○ Jika $\mathrm{r}$ hitung $>\mathrm{r}$ tabel (uji 2 sisi dengan sig. 0,05) maka instrumen atau item-item pertanyaan berkorelasi signifikan terhadap skor total (dinyatakan valid).

- Jika $\mathrm{r}$ hitung $<\mathrm{r}$ tabel (uji 2 sisi dengan sig. 0,05) maka instrumen atau item-item pertanyaan tidak berkorelasi signifikan terhadap skor total (dinyatakan tidak valid).

b) Uji Reliabilitas

Pengujian ini menggunakan metode Cronbach Alpha dengan nilai sebesar 0,06. Apabila Cronbach Alpha < 0,6, maka butir pertanyaan tersebut tidak reliable

2) Uji Asumsi Klasik

a) Uji Multikolonieritas

Dilakukan dengan menghitung nilai Variance Inflation Factor (VIF) dari tiaptiap variabel independen. Nilai VIF kurang dari 10 menunjukkan bahwa korelasi antar variabel independen masih bisa ditolerir.

b) Uji Heterodedastisitas

Dilakukan menggunakan metode Uji Glejser, dimana Uji Gejser dimaksudkan untuk meregresinilai absoluteresidual terhadap variabel independen .Dengan syarat nilai signifikan> 0,05 maka tidak terjadi heteroskedastisitas.

3) Uji Normalitas

Penelitian yang menggunakan metode yang lebih handal untuk menguji data mempunyai distribusi normal atau tidak yaitu dengan melihat grafik Normal Probability Plot. Model regresi yang baik adalah data distribusi normal atau mendekati normal.Untuk mendeteksi normalitas dapat dilakukan dengan melihat penyebaran data (titik) pada sumbu diagonal grafik (Ghozali, Imam. 2009).

4) Uji Hipotesis

a) Uji persamaan regresi linear berganda Untuk menguji hipotesis tersebut, maka rumus persamaan regresi yang digunakan adalah sebagai berikut: 


\section{Metodologi Penelitian}

Keterangan:

$\mathrm{Y}=$ Variabel Dependen (Terikat)

$\mathrm{a}=$ Konstanta

b1, b2, .. b7 = Koefisien regresi untuk X1, $\mathrm{X} 2, \ldots . \mathrm{Xn}$

$\mathrm{X} 1=$ Variabel Independen 1 (Bebas)

$\mathrm{X} 2=$ Variabel Independen 2 (Bebas)

$\mathrm{Xn}=$ Variabel Independen $\mathrm{n}$ (Bebas)

5) Uji t Parsial

a) Jika nilai signifikansi $<0,05$ maka berarti variabel independen atau variabel $X$ secara parsial berpengaruh terhadap variabel dependen atau variabel $Y$.

b) Jika nilai $t_{\text {hitung }}>t_{\text {abel }}$ maka artinya variabel independen (X) secara parsial berpengaruh terhadap variabel dependent (Y). Dasar pengambilan keputusan uji $t$ parsial berdasarkan nilai hitung dan tabel dapat ditentukan dengan rumus :

$$
\mathbf{t}_{\text {tabel }}=(\alpha / 2: n-k-1)
$$

6) Uji F Simultan

○ jika nilai signifikansi $<0,05$ maka berarti variabel independen atau variabel $X$ secara simultan berpengaruh terhadap variabel dependen atau variabel $\mathrm{Y}$.

○ jika nilai $\mathrm{F}_{\text {hitung }}>\mathrm{Ft}_{\mathrm{abel}}$ maka artinya variabel independen $(\mathrm{X})$ secara simultan berpengaruh terhadap variabel dependent (Y). Dasar pengambilan keputusan uji $\mathrm{F}$ simultan berdasarkan nilai hitung dan tabel dapat ditentukan dengan rumus:

$$
\mathbf{F}_{\text {tabel }}=(\mathbf{k} ; \mathbf{n}-\mathbf{k})
$$

Berikut adalah diagram alir penelitian

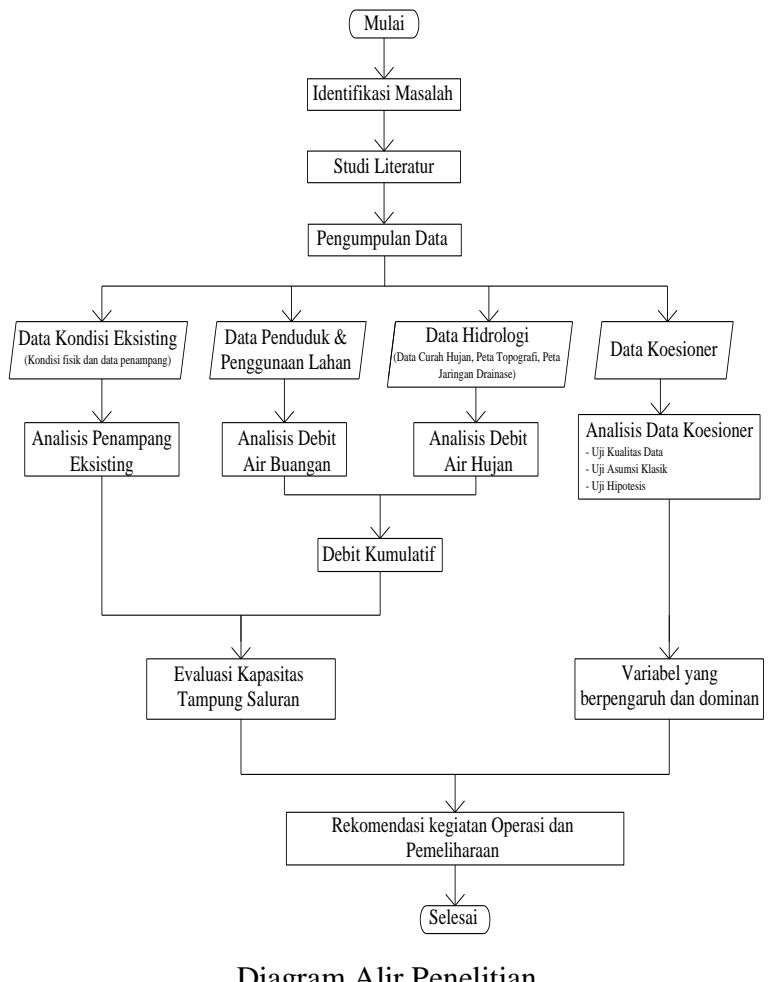

IV. Hasil dan Pembahasan

\section{A. Analisis Kondisi Eksisting}

Lokasi penelitian ini yaitu Drainase Sinrijala masuk pada wilayah kecamatan Rappocini, Tamalate dan Makassar kota Makassar dengan panjang saluran drainase $2,363 \mathrm{~km}$.

Survey pengukuran di lapangan, ditetapkan 34 patok pengamatan dengan interval rata-rata $50 \mathrm{~m}$, namun disesuaikan pula dengan kondisi di lapangan. Survey yang dilakukan berupa pengukuran memajang (long) dan melintang (cross). Titik awal patok (P.0) di mulai pada daerah muara Drainase Sinrijala yakni di percabangan Kanal Sinrijala - Sungai Pampang. Dan titik akhir pengukuran (P.34) pada daerah hulu Drainase Sinrijala di percabangan Drainase Sinrijala - Drainase Jongaya dan Panampu. 


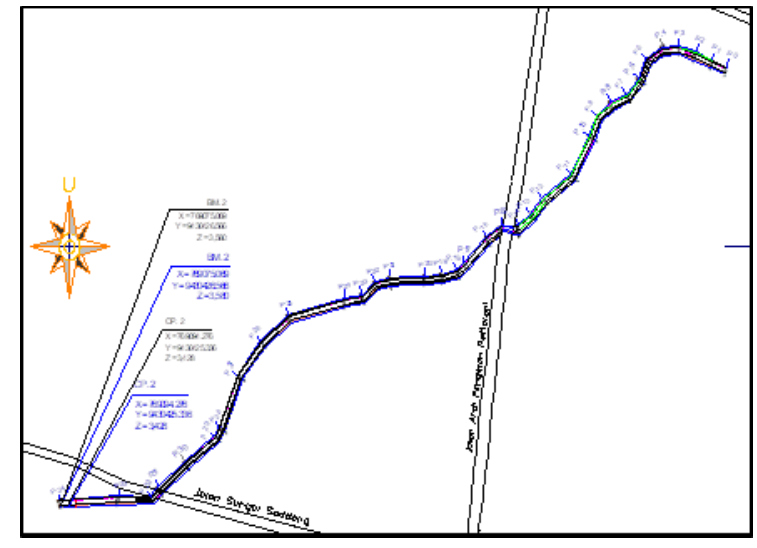

Gambar Plotting Titik-titik Pengukuran

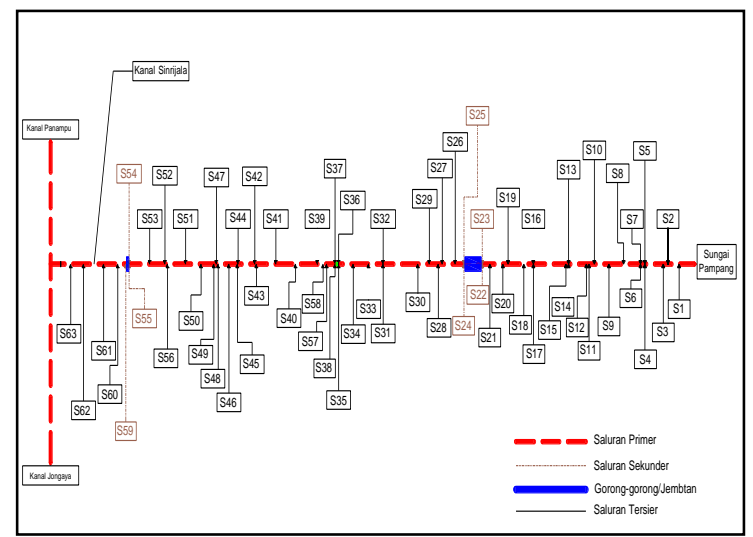

Gambar Skema Jaringan Drainase Sinrijala

Drainase Sinrijala merupakan saluran utama yang membuang air dari kumpulan saluran sekunder dan tersier ke badan air atau sungai yang memiliki cathment area seluas $=0,8489 \mathrm{~km}^{2}$.

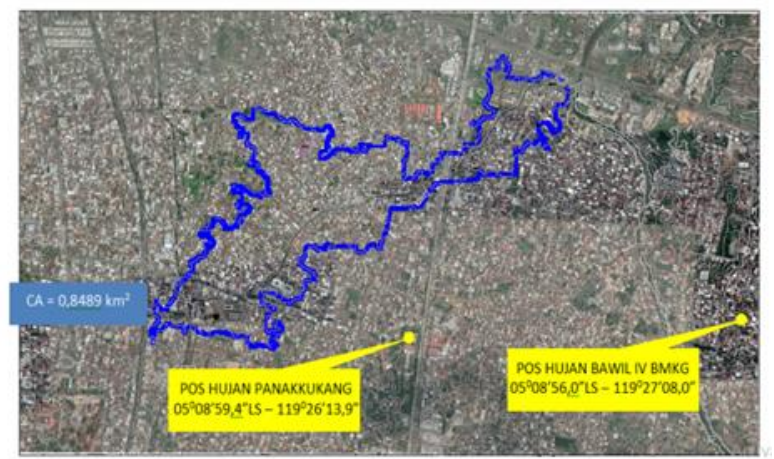

Gambar Cathment Area Drainase Sinrijala

Berdasarkan hasil survey di lapangan,kemiringan dasar saluran terjadi kelandaian pada beberapa titik saluran.. Hal tersebut mengakibatkan laju aliran sangat lambat menuju ke muara sungai Pampang.

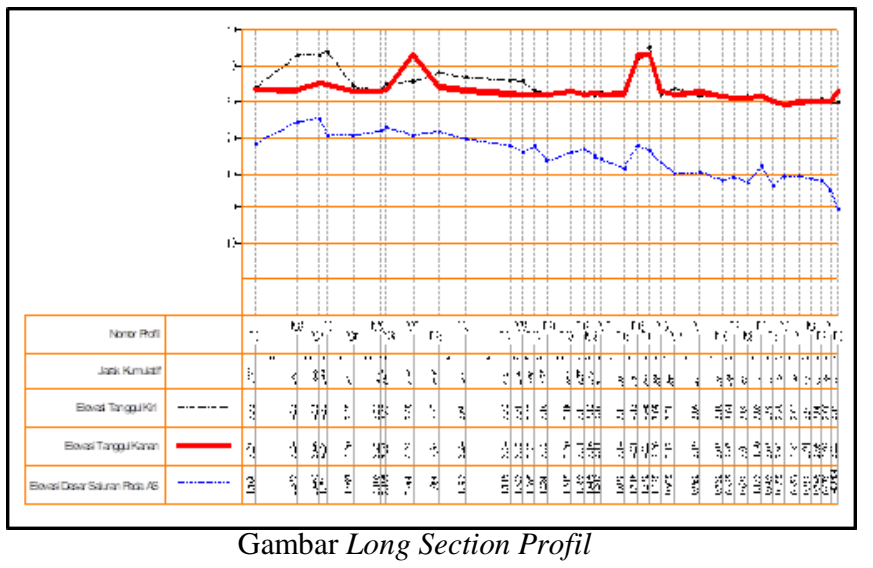

Tabel Kondisi Eksisting Drainase Sinrijala

\begin{tabular}{|c|c|c|}
\hline \multicolumn{3}{|l|}{ Dinding Saluran } \\
\hline Kondisi & Panjang (km) & Persentase (\%) \\
\hline Baik & 2,819 & 59,649 \\
\hline Rusak Sedang & 1,660 & 35,114 \\
\hline Rusak Berat & 0,248 & 0,248 \\
\hline \multicolumn{3}{|l|}{ Outlet Saluran } \\
\hline \multirow[t]{2}{*}{ Penampang } & Ukuran & Jumlah \\
\hline & $\varnothing<0,2 \mathrm{~m}$ & 11 \\
\hline \multirow[t]{2}{*}{ Lingkaran } & $\varnothing 0,2-1,0 \mathrm{~m}$ & 30 \\
\hline & $\varnothing>1 \mathrm{~m}$ & 3 \\
\hline \multirow{3}{*}{ Persegi } & $<0,2 \times 0,2 \mathrm{~m}$ & 5 \\
\hline & $0,2 \times 0,2 \mathrm{~m}-1,0 \times 1,0 \mathrm{~m}$ & 11 \\
\hline & $>1,0-1,0 \mathrm{~m}$ & 4 \\
\hline \multicolumn{3}{|l|}{ Tanggul } \\
\hline Kondisi & Panjang $(\mathrm{km})$ & Persentase $(\%)$ \\
\hline Baik & 0,667 & 14,163 \\
\hline Belum Memiliki Tanggul & 4,057 & 85,837 \\
\hline \multicolumn{3}{|l|}{ Pengaman Kanal (railing) } \\
\hline Kondisi & Panjang $(\mathrm{m})$ & Persentase $(\%)$ \\
\hline Baik & 858,365 & 18,163 \\
\hline Rusak & 1330,084 & 28,144 \\
\hline Belum Memiliki Railing & 2537,551 & 53,693 \\
\hline \multicolumn{3}{|l|}{ Jalan Inspeksi } \\
\hline Paving Block & 2692,041 & 56,962 \\
\hline Aspal & 1137,811 & 24,076 \\
\hline Perkerasan Tanah Biasa & 137,323 & 2,906 \\
\hline Belum Memiliki Jalan & 758,825 & 16,056 \\
\hline \multicolumn{3}{|l|}{ Pintu Air } \\
\hline \multicolumn{3}{|c|}{ Tidak difungsikan sebagaimana mestinya dan kurang dirawat } \\
\hline \multicolumn{3}{|l|}{ Trash Rack } \\
\hline \multicolumn{3}{|c|}{ Belum terdapat trash rack } \\
\hline \multicolumn{3}{|l|}{ Pompa Banjir } \\
\hline & terdapat pompa banjir & \\
\hline
\end{tabular}

\section{B. Analisis Data Penduduk}

Jumlah penduduk pada daerah layanan Drainase Sinrijala terdiri dari kecamatan Rappocini dengan luas $0,278 \mathrm{~km}^{2}$ sebesar 5566 jiwa, kecamatan Tamalate dengan luas $0,189 \mathrm{~km}^{2}$ sebesar 4752 jiwa dan kecamatan Makassar dengan luas $0,382 \mathrm{~km}^{2}$ sebesar 13477 jiwa. Jadi jumlah penduduk pada daerah layanan dengan total $0,849 \mathrm{~km}^{2}$ sebesar 23755 jiwa. 


\section{Analisis Hidrologi}

1) Uji Konsistensi

Tabel RAPS Stasiun Panakukkang

\begin{tabular}{|c|c|c|c|c|c|c|}
\hline Tahiun & $\begin{array}{c}\text { Hujan } \\
\text { Harian } \\
\text { Max }\end{array}$ & $\mathrm{Sk}^{*}$ & {$\left[\mathrm{Sk}^{*}\right]$} & Dy2 & $\mathrm{Sk}^{* *}$ & {$\left[\mathrm{Sk}^{* *}\right]$} \\
\hline 2010 & 91,00 & 45,44 & $-45,444$ & 206.52 & 0,42077 & $-0,4208$ \\
\hline 2011 & 90,00 & 46,44 & $-46,444$ & 215,71 & 0,43003 & $-0,43$ \\
\hline 2012 & 115,00 & 21,44 & $-21,444$ & 45,99 & 0,19856 & $-0,1986$ \\
\hline 2013 & 193,00 & $-56,56$ & 56,5556 & 319,85 & $-0,5237$ & 0,52365 \\
\hline 2014 & 135,00 & 1,44 & $-1,4444$ & 0,21 & 0,01337 & $-0,0134$ \\
\hline 2015 & 139,00 & $-2,56$ & 2,55556 & 0,65 & $-0,0237$ & 0,02366 \\
\hline 2016 & 142,00 & $-5,56$ & 5,55556 & 3,09 & $-0,0514$ & 0,05144 \\
\hline 2017 & 178,00 & $-41,56$ & 41,5556 & 172,69 & $-0,3848$ & 0,38476 \\
\hline 2018 & 145,00 & $-8,56$ & 8,55556 & 7,32 & $-0,0792$ & 0,07922 \\
\hline Rata-rata & 136,44 & \multicolumn{2}{|c|}{ Dy } & 108,00 & & \\
\hline \multicolumn{2}{|c|}{$\mathrm{N}$} & \multicolumn{5}{|c|}{9} \\
\hline \multicolumn{2}{|c|}{ Dy } & \multicolumn{5}{|c|}{108} \\
\hline \multicolumn{2}{|c|}{ Sk**maks } & \multicolumn{5}{|c|}{0,43} \\
\hline \multicolumn{2}{|c|}{$\mathrm{Sk}^{* *} \min$} & \multicolumn{5}{|c|}{$-0,52$} \\
\hline \multicolumn{2}{|c|}{ Q } & \multicolumn{5}{|c|}{0,43} \\
\hline \multicolumn{2}{|c|}{ R } & \multirow{2}{*}{\multicolumn{5}{|c|}{$\frac{0,92}{0,14}$}} \\
\hline \multicolumn{2}{|c|}{$\mathrm{Q} / \sqrt{\mathrm{n}}$} & & & & & \\
\hline \multicolumn{2}{|c|}{$\mathrm{R} / \mathrm{n}$} & \multicolumn{5}{|c|}{0,32} \\
\hline
\end{tabular}

Tabel RAPS Stasiun Bawail IV

\begin{tabular}{|c|c|c|c|c|c|c|}
\hline Tahun & $\begin{array}{c}\text { Hujan } \\
\text { Harian } \\
\text { Max }\end{array}$ & Sk* & {$\left[\mathrm{Sk}^{*}\right]$} & Dy2 & Sk** & {$\left[\mathrm{Sk}^{* *}\right]$} \\
\hline 2015 & 169,00 & $-16,60$ & 16,6 & 27,56 & $-0,373$ & 0,373 \\
\hline 2016 & 173,00 & $-20,60$ & 20,6 & 42,44 & $-0,4629$ & 0,46288 \\
\hline 2017 & 166,00 & $-13,60$ & 13,6 & 18,50 & $-0,3056$ & 0,30559 \\
\hline 2018 & 132,00 & 20,40 & $-20,4$ & 41,62 & 0,45839 & $-0,4584$ \\
\hline 2019 & 122,00 & 30,40 & $-30,4$ & 92,42 & 0,68308 & $-0,6831$ \\
\hline Rata-rata & 152,40 & \multicolumn{2}{|c|}{ Dy } & \multicolumn{2}{|c|}{44,50} & \\
\hline \multicolumn{2}{|c|}{$\mathrm{N}$} & \multicolumn{5}{|c|}{5} \\
\hline \multicolumn{2}{|c|}{ Dy } & \multicolumn{5}{|c|}{44,50} \\
\hline \multicolumn{2}{|c|}{ Sk**maks } & \multicolumn{5}{|c|}{0,68} \\
\hline \multicolumn{2}{|c|}{$\mathrm{Sk} * \mathrm{Sk}^{*}$} & \multicolumn{5}{|c|}{$-0,46$} \\
\hline \multicolumn{2}{|c|}{ Q } & \multicolumn{5}{|c|}{0,68} \\
\hline \multicolumn{2}{|c|}{$R$} & \multicolumn{5}{|c|}{1,15} \\
\hline \multicolumn{2}{|c|}{$\mathrm{Q} / \mathrm{/n}$} & \multicolumn{5}{|c|}{0,31} \\
\hline \multicolumn{2}{|c|}{$\mathrm{R} / \sqrt{\mathrm{n}}$} & & & 0,51 & & \\
\hline
\end{tabular}

2) Analisa Curah Hujan Maksimum Harian Rata-Rata Tabel Hujan Wilayah

\begin{tabular}{ccccc}
\hline \multirow{2}{*}{ No } & \multirow{2}{*}{ Tahun } & \multicolumn{2}{c}{ Stasiun Curah Hujan } & \multirow{2}{*}{ Hujan Wilayah } \\
\cline { 3 - 4 } & & Panakuk ang & Bawil 4 & \\
\hline 1 & 2010 & 91 & - & 91 \\
\hline 2 & 2011 & 90 & - & 90 \\
\hline 3 & 2012 & 115 & - & 115 \\
\hline 4 & 2013 & 193 & - & 193 \\
\hline 5 & 2014 & 135 & - & 135 \\
\hline 6 & 2015 & 139 & 169 & 154 \\
\hline 7 & 2016 & 142 & 173 & 157.5 \\
\hline 8 & 2017 & 178 & 166 & 172 \\
\hline 9 & 2018 & 145 & 132 & 138.5 \\
\hline 10 & 2019 & - & 122 & 122 \\
\hline \multicolumn{5}{c}{ Jumlah } \\
\hline \multicolumn{5}{c}{ Rh rata-rata (X) } \\
\hline Sumber : Hasil Olah Data : 2020 & 1368,00 \\
\hline
\end{tabular}

3) Analisis Distribusi Frekuensi

Tabel Parameter Statistik Curah Hujan

\begin{tabular}{|c|c|c|c|c|c|c|c|}
\hline No & Tahun & $\begin{array}{l}\mathrm{Rh} \\
\left(\mathrm{X}_{1}\right)\end{array}$ & $\begin{array}{l}\text { Rhrata- } \\
\text { tata }(X)\end{array}$ & $\left(\mathrm{X}_{1}-\mathrm{X}\right)$ & $\left(X_{1}-X\right)^{2}$ & $(\mathrm{X} 1-X)^{3}$ & $\left(X_{1}-X\right)^{4}$ \\
\hline 1 & 2010 & 91 & 136,80 & $-45,80$ & 2097,64 & $-96071,91$ & 4400093,57 \\
\hline 2 & 2011 & 90 & 136,80 & $-46,80$ & 2190,24 & $-102503,23$ & 4797151,26 \\
\hline 3 & 2012 & 115 & 136,80 & $-21,80$ & 475,24 & $-10360,23$ & 225853,06 \\
\hline 4 & 2013 & 193 & 136,80 & 56,20 & 3158,44 & 177504,33 & 9975743,23 \\
\hline 5 & 2014 & 135 & 136,80 & $-1,80$ & 3,24 & $-5,83$ & 10,50 \\
\hline 6 & 2015 & 154 & 136,80 & 17,20 & 295,84 & 5088,45 & 87521,31 \\
\hline 7 & 2016 & 157.5 & 136,80 & 20,70 & 428,49 & 8869,74 & 183603,68 \\
\hline 8 & 2017 & 172 & 136,80 & 35,20 & 1239,04 & 43614,21 & 1535220,12 \\
\hline 9 & 2018 & 138,5 & 136,80 & 1,70 & 2,89 & 4,91 & 8,35 \\
\hline 10 & 2019 & 122 & 136,80 & $-14,80$ & 219,04 & $-3241,79$ & 47978,52 \\
\hline Jumlah & 1368 & - & 0,00 & 10110,10 & 22898,64 & 21253183,00 & \\
\hline Rata-rata & 136.8 & - & - & - & - & - & \\
\hline $\begin{array}{l}\text { Standar } \\
\text { Deviasi }\end{array}$ & \multicolumn{7}{|c|}{33,52} \\
\hline $\mathrm{N}$ & \multirow{2}{*}{\multicolumn{7}{|c|}{$\frac{10}{0.08}$}} \\
\hline $\mathrm{Cs}$ & & & & & & & \\
\hline $\mathrm{Ck}$ & \multicolumn{7}{|c|}{3,34} \\
\hline $\mathrm{Cv}$ & \multicolumn{7}{|c|}{0.25} \\
\hline
\end{tabular}

Tabel Uji Distribusi Frekuensi

\begin{tabular}{|c|c|c|c|c|}
\hline No & $\begin{array}{c}\text { Jenis } \\
\text { Distribusi }\end{array}$ & Syarat & $\begin{array}{c}\text { Hasil } \\
\text { Hitungan }\end{array}$ & Kesimpulan \\
\hline \multirow{2}{*}{1} & \multirow{2}{*}{ Normal } & $\mathrm{Cs} \approx 0$ & $\mathrm{Cs}=0,08$ & $\begin{array}{c}\text { Tidak } \\
\text { Memenuhi }\end{array}$ \\
\hline & & $\mathrm{Ck}=3$ & $\mathrm{Ck}=3,34$ & $\begin{array}{c}\text { Tidak } \\
\text { Memenuhi }\end{array}$ \\
\hline 2 & Log Normal & $\mathrm{Cs} \approx 3 \mathrm{Cv}$ & $\mathrm{Cs}=0,08$ & $\begin{array}{c}\text { Tidak } \\
\text { Memenuhi }\end{array}$ \\
\hline \multirow{2}{*}{3} & \multirow{2}{*}{ Gumbel } & $\mathrm{Cs} \approx 1,14$ & $\mathrm{Cs}=0,08$ & $\begin{array}{c}\text { Tidak } \\
\text { Memenuhi }\end{array}$ \\
\hline & & $\mathrm{Ck} \approx 5,4002$ & $\mathrm{Ck}=3,34$ & $\begin{array}{c}\text { Tidak } \\
\text { Memenuhi }\end{array}$ \\
\hline \multirow{2}{*}{4} & \multirow{2}{*}{$\begin{array}{l}\text { Log } \\
\text { Pearson } \\
\text { Type III }\end{array}$} & \multirow{2}{*}{$\begin{array}{l}\text { Cs positif atau negatif } \\
\text { dan tidak memenuhi } \\
\text { semua syarat diatas }\end{array}$} & $\mathrm{Cs}=0,08$ & Memenuhi \\
\hline & & & $\mathrm{Ck}=3,34$ & Memenuhi \\
\hline
\end{tabular}

4) Perhitungan Distribusi Probabilitas

Tabel Perhitungan Log Pearson Type III

\begin{tabular}{|c|c|c|c|c|c|}
\hline No & Tahun & $\mathrm{Xi}$ & Log Xi & $(\log X i-\log X)^{2}$ & $(\log X i-\log X)^{3}$ \\
\hline 1 & 2010 & 91 & 1,959 & 0,02715 & $-0,00447$ \\
\hline 2 & 2011 & 90 & 1,954 & 0,02875 & $-0,00487$ \\
\hline 3 & 2012 & 115 & 2,061 & 0,00398 & $-0,00025$ \\
\hline 4 & 2013 & 193 & 2,286 & 0,02617 & 0,00423 \\
\hline 5 & 2014 & 135 & 2,130 & 0,00004 & 0,00000 \\
\hline 6 & 2015 & 154 & 2,188 & 0,00406 & 0,00026 \\
\hline 7 & 2016 & 157.5 & 2,197 & 0,00540 & 0,00040 \\
\hline 8 & 2017 & 172 & 2,236 & 0,01248 & 0,00139 \\
\hline 9 & 2018 & 138.5 & 2,141 & 0,00031 & 0,00001 \\
\hline 10 & 2019 & 122 & 2,086 & 0,00140 & $-0,00005$ \\
\hline & Jumlah & & 21,238 & 0,10974 & $-0,00336$ \\
\hline & $\log X$ & & \multicolumn{3}{|c|}{2,124} \\
\hline & $\mathrm{S}$ & & \multicolumn{3}{|c|}{0,110} \\
\hline & Cs & & \multicolumn{3}{|c|}{$-0,347$} \\
\hline
\end{tabular}

Tabel Nilai G Interpolasi

\begin{tabular}{ccccccc}
\hline $\operatorname{Tr}$ & $\mathrm{G}$ & $\mathrm{Cs} 1$ & $\mathrm{Cs}$ & $\mathrm{Cs} 2$ & $\mathrm{G} 1$ & $\mathrm{G} 2$ \\
\hline 2 & 0,058 & $-0,3$ & $-0,347$ & $-0,4$ & 0,050 & 0,066 \\
\hline 5 & 0,854 & $-0,3$ & $-0,347$ & $-0,4$ & 0,853 & 0,855 \\
\hline \multicolumn{7}{l}{ Sumber : Hasil Olah Data : 2020}
\end{tabular}


Tabel Hasil Perhitungan Log Pearson Type III

\begin{tabular}{cccccc}
\hline $\operatorname{Tr}$ & $\log \mathrm{X}$ & $\mathrm{G}$ & $\mathrm{S}$ & $\log \mathrm{G}$ & $\mathrm{Rt}(\mathrm{mm})$ \\
\hline 2 & 2,124 & 0,058 & 0,110 & 2,130 & 134,943 \\
\hline 5 & 2,124 & 0,854 & 0,110 & 2,218 & 165,233 \\
\hline \multicolumn{7}{l}{ Sumber : Hasil Olah Data $: 2020$} \\
\end{tabular}

Tabel Curah Hujan Rencana Periode Ulang T Tahun dengan Metode Log Pearson Type III

\begin{tabular}{cc}
\hline Periode Ulang (Tahun) & Curah Hujan Rencana (mm) \\
\hline 2 & 134,943 \\
\hline 5 & 165,233 \\
\hline Sumber : Hasil Olah Data : 2020 &
\end{tabular}

5) Pengujian Distribusi Probabilitas

Tabel Distribusi Probabilitas dengan Chi Kuadrat

\begin{tabular}{|c|c|c|c|c|c|}
\hline \multirow{2}{*}{ No } & \multirow{2}{*}{$\begin{array}{c}\text { Probabilitas } \\
(\%)\end{array}$} & \multicolumn{2}{|c|}{ Jumlah Data } & \multirow{2}{*}{$\mathrm{Oi}-\mathrm{Ei}$} & \multirow{2}{*}{$\mathrm{X}^{2}=\left((\mathrm{Oi}-\mathrm{Ei})^{2}\right) / \mathrm{E}$} \\
\hline & & Oi & $\mathrm{Ei}$ & & \\
\hline 1 & $77<x<112$ & 2 & 2 & 0 & 0 \\
\hline 2 & $112<x<147$ & 4 & 2 & 2 & 2 \\
\hline 3 & $147<x<182$ & 3 & 2 & 1 & 0,5 \\
\hline 4 & $182<\mathrm{x}<217$ & 1 & 2 & -1 & 0,5 \\
\hline 5 & $x>217$ & 0 & 2 & -2 & 2 \\
\hline & Jumlah & 10 & 10 & 0 & 5 \\
\hline
\end{tabular}

Tabel Uji Distribusi Probabilitas Smirnov Kolmogorov

\begin{tabular}{cccccccc}
\hline $\mathrm{M}$ & $\mathrm{Xi}$ & $\begin{array}{c}\mathrm{P}(\mathrm{x})= \\
\mathrm{M} /(\mathrm{n}+1)\end{array}$ & $\mathrm{P}(\mathrm{x}<)$ & $\begin{array}{c}\mathrm{f}(\mathrm{t})= \\
(\mathrm{Xi}-\mathrm{Xrt}) / \mathrm{sd}\end{array}$ & $\begin{array}{c}\mathrm{P}^{\prime}(\mathrm{x})= \\
\mathrm{M} /(\mathrm{n}-1)\end{array}$ & $\mathrm{P}^{\prime}(\mathrm{x}<)$ & $\mathrm{D}$ \\
\hline 1 & 2 & 3 & $\begin{array}{c}4=\text { nilai } \\
1-3\end{array}$ & 5 & 6 & $\begin{array}{c}7=\text { nilai } \\
1-6\end{array}$ & $8=4-7$ \\
\hline 1 & 91 & 0,091 & 0,909 & $-1,366$ & 0,111 & 0,889 & 0,020 \\
\hline 2 & 90 & 0,182 & 0,818 & $-1,396$ & 0,222 & 0,778 & 0,040 \\
\hline 3 & 115 & 0,273 & 0,727 & $-0,650$ & 0,333 & 0,667 & 0,061 \\
\hline 4 & 193 & 0,364 & 0,636 & 1,677 & 0,444 & 0,556 & 0,081 \\
\hline 5 & 135 & 0,455 & 0,545 & $-0,054$ & 0,556 & 0,444 & 0,101 \\
\hline 6 & 154 & 0,545 & 0,455 & 0,513 & 0,667 & 0,333 & 0,121 \\
\hline 7 & 157,5 & 0,636 & 0,364 & 0,618 & 0,778 & 0,222 & 0,141 \\
\hline 8 & 172 & 0,727 & 0,273 & 1,050 & 0,889 & 0,111 & 0,162 \\
\hline 9 & 138,5 & 0,818 & 0,182 & 0,051 & 1,000 & 0,000 & 0,182 \\
\hline 10 & 122 & 0,909 & 0,091 & $-0,442$ & 1,111 & $-0,111$ & 0,202 \\
\hline \multicolumn{7}{c}{ Dmax } \\
\hline
\end{tabular}

Sumber: Hasil Olah Data : 2020
6) Perhitungan Intensitas Hujan Rencana Tabel Intensitas Curah Hujan

\begin{tabular}{|c|c|c|}
\hline \multirow{3}{*}{$\mathrm{t}(\mathrm{jam})$} & \multicolumn{2}{|c|}{ R24 } \\
\hline & $\mathrm{R} 2$ & R5 \\
\hline & 134,943 & 165,233 \\
\hline 1 & 46,782 & 57,283 \\
\hline 2 & 29,471 & 36,086 \\
\hline 3 & 22,491 & 27,539 \\
\hline 4 & 18,566 & 22,733 \\
\hline 5 & 15,999 & 19,591 \\
\hline 6 & 14,168 & 17,348 \\
\hline 7 & 12,784 & 15,654 \\
\hline 8 & 11,696 & 14,321 \\
\hline 9 & 10,812 & 13,239 \\
\hline 10 & 10,079 & 12,341 \\
\hline 11 & 9,458 & 11,581 \\
\hline 12 & 8,925 & 10,929 \\
\hline 13 & 8,462 & 10,361 \\
\hline 14 & 8,054 & 9,861 \\
\hline 15 & 7,692 & 9,418 \\
\hline 16 & 7,368 & 9,022 \\
\hline 17 & 7,076 & 8,664 \\
\hline 18 & 6,811 & 8,340 \\
\hline 19 & 6,570 & 8,045 \\
\hline $\mathrm{t}$ (jam) & R2 & R5 \\
\hline 20 & 6,349 & 7,775 \\
\hline 21 & 6,146 & 7,526 \\
\hline 22 & 5,958 & 7,296 \\
\hline 23 & 5,784 & 7,083 \\
\hline 24 & 5,623 & 6,885 \\
\hline
\end{tabular}

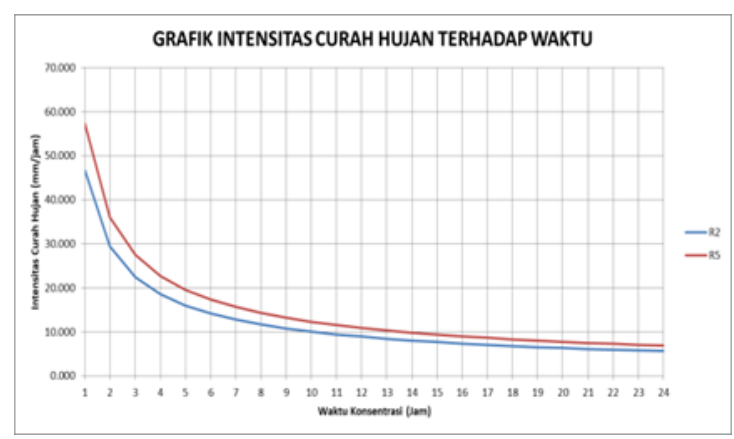

Gambar Grafik Intensitas Curah Hujan

7) Waktu konsentrasi (tc)

Tabel Perhitungan Intensitas Curah Hujan untuk Saluran Drainase Sinrijala

\begin{tabular}{cccc}
\hline Periode Ulang & R (mm) & tc $(\mathrm{jam})$ & $\mathrm{I}(\mathrm{mm} / \mathrm{j}$ am) \\
\hline T2 & 134,943 & 1,997 & 29,499 \\
\hline T5 & 165,233 & 1,997 & 36,120 \\
\hline Sumber : Hasil Olah Data $: 2020$ & &
\end{tabular}


8) Perhitungan Debit Air Hujan Rencana

Tabel Luas Koefisien Aliran

\begin{tabular}{clccc}
\hline No & Jenis Tata Guna Lahan & Luas (m2) & Nilai C & A . C \\
\hline 1 & multiunit terpisah & 59820,53 & 0,40 & 333561,548 \\
\hline 2 & multiunit tergabung & 647126,10 & 0,65 & 420631,965 \\
\hline 3 & industri kecil & 41456,59 & 0,50 & 20728,295 \\
\hline 4 & bisnis perkotaan & 4716,54 & 0,70 & 3301,578 \\
\hline 5 & lahan terbuka & 32159,47 & 0,20 & 6431,894 \\
\hline 6 & jalan aspal & 24175,64 & 0,85 & 20549,294 \\
\hline 7 & jalan paving block & 16318,98 & 0,60 & 9791,388 \\
\hline 8 & industri besar & 2322,13 & 0,90 & 2089,917 \\
\hline 9 & taman tempat bermain & 5807,89 & 0,20 & 1161,578 \\
\hline \multicolumn{2}{c}{ Total } & 833903,87 & - & 818247,457 \\
\hline & & Cgab & 0,981 \\
\hline & & \multicolumn{3}{l}{}
\end{tabular}

Tabel Debit Hujan pada Kawasan Drainase Sinrijala

\begin{tabular}{cccccc}
\hline No & $\begin{array}{c}\text { Periode } \\
\text { Ulang }\end{array}$ & $\mathrm{I}(\mathrm{mm} / \mathrm{jam})$ & $\mathrm{C}$ & $\mathrm{A}\left(\mathrm{m}^{2}\right)$ & $\begin{array}{c}\text { Q Hujan } \\
\left(\mathrm{m}^{3} / \mathrm{det}\right)\end{array}$ \\
\hline 1 & $\mathrm{~T} 2$ & 29,499 & 0,981 & 833903,87 & 6,710 \\
\hline 2 & $\mathrm{~T} 5$ & 36,120 & 0,981 & 833903,87 & 8,216 \\
\hline
\end{tabular}

Sumber : Hasil Olah Data : 2020

9) Perhitungan Debit Air Kotor

Adapun besarnya kebutuhan air penduduk rata-rata adalah 150 liter/orang/hari. Sedangkan debit air kotor yang harus dibuang didalam saluran adalah $70 \%$ dari kebutuhan air bersih (Suhardjini, 1984:39).

Rumus :

$$
\begin{array}{cl} 
& \text { Qak }=\frac{p n \times q}{A} \\
\mathrm{q} \quad & 150 \times 70 \% \\
= & 105 \text { liter/orang/hari }=0,00121 \\
\text { liter/dtk/orang }
\end{array}
$$

Total jumlah debit pada saluran adalah Qak $=2,088$.

10) Debit Komulatif

Tabel Debit Kumulatif

\begin{tabular}{ccccc}
\hline No & $\begin{array}{c}\text { Periode Ulang } \\
\text { (Tahun) }\end{array}$ & $\begin{array}{c}\text { Q Hujan } \\
\text { (m3/det) }\end{array}$ & $\begin{array}{c}\text { Q Buangan } \\
\text { (m3/det) }\end{array}$ & $\begin{array}{c}\text { Q Banjir } \\
\text { (m3/det) }\end{array}$ \\
\hline 1 & T2 & 6,710 & 2,088 & 8,798 \\
\hline 2 & T5 & 8,216 & 2,088 & 10,304 \\
\hline \multicolumn{2}{l}{ Sumber : Hasil Olah Data : 2020}
\end{tabular}

\section{Analisis Hidrolika}

Berdasarkan data pengukuran memanjang (long) dan melintang (cross) yang telah didapatkan pada pengukuran lapangan, kemudian diinput ke dalam software HEC-RAS 4.1.0 untuk kemudian dilakuan pemodelan data geometri. Dalam menjalankan program HEC-RAS maka sebagai langkah awal adalah input data yang meliputi : a) Skema sistem sungai (River System Schematic)

b) Data Penampang sungai (Cross Section Data)

c) Jarak antar patok (Left of Bank/LOB, Channel dan Right of Bank/ROB)

d) Parameter setiap data penampang yang terdiri dari kekasaran manning (n) dan 2 titik koordinat yang membentuk penampang utama (Main Channel Bank Station).

Data Aliran tetap meliputi : Kondisi Batas (Boundary Conditions).

Dalam analisa profil aliran ini akan dihitung dengan beberapa kondisi antara lain :

1) Kondisi muka air pada debit kala ulang 2 th (Q2)

2) Kondisi muka air pada debit kala ulang 5 th (Q5) Berikut hasil analisa profil muka air dengan menggunakan program HEC-RAS.

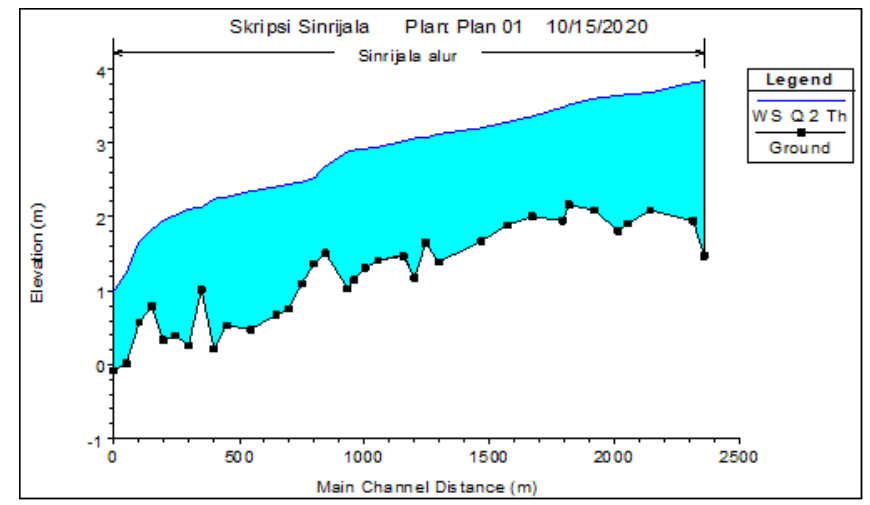

Gambar Profil Muka Air Drainase Sinrijala dengan Debit Kala Ulang 2 Tahun

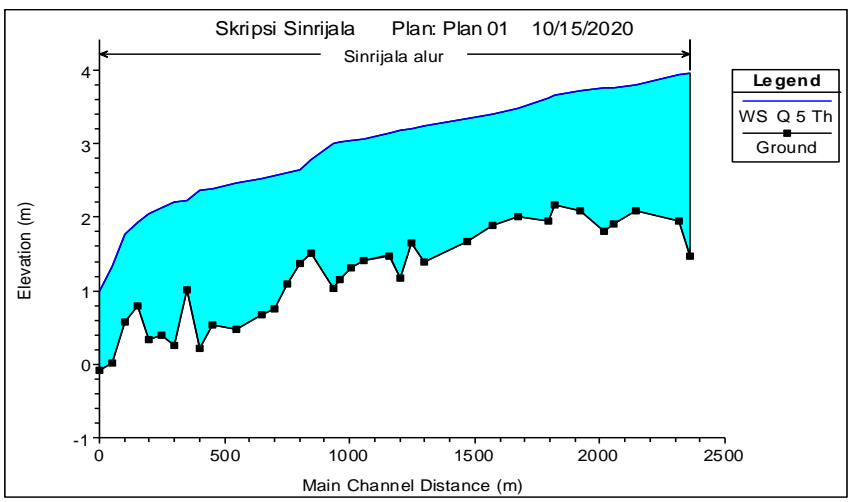

Gambar Profil Muka Air Drainase Sinrijala dengan Debit Kala Ulang 5 Tahun

Berdasarkan hasil analisis hidrolika menggunakan aplikasi HEC-RAS diperoleh bahwa terdapat beberapa bagian pada eksisting drainase mempunyai muka air banjir melebihi kapasitas drainase.

1) Debit rancangan kala ulang 2 tahun

a) Pada P.28, P.29, P.30, dan P.34 air meluap pada tanggul sebelah kiri dan kanan karena memiliki 
elevasi banjir yang lebih tinggi dari pada elevasi tanggul kiri dan kanan.

b) Pada P.24, P.25, P.26, P.32, dan P.33 air meluap pada tanggul sebelah kanan karena memiliki elevasi banjir yang lebih tinggi dari pada elevasi tanggul kanan.

c) Pada P.16, P.17, P.18, P.19, P.20, P.21, P.22, P.28, P.29, P.30, dan P.34 tidak memenuhi syarat tinggi jagaan pada tanggul sebelah kiri dan kanan karena memiliki tinggi jagaan $<0,3$ meter.

d) Pada P.27 tidak memenuhi syarat tinggi jagaan pada tanggul sebelah kiri karena memiliki tinggi jagaan $<0,3$ meter.

e) Pada P.23, P.24, P.25, P.26, P.32, dan P.33 tidak memenuhi syarat tinggi jagaan pada tanggul sebelah kanan karena memiliki tinggi jagaan $<0,3$ meter.

f) Selain penampang yang telah disebutkan pada point a, b, c, d, dan e, memiliki elevasi tanggul yang lebih tinggi dari pada elevasi banjir kala ulang 2 dan 5tahun sehingga air tidak meluap. Selain itu, telah memenuhi syarat tinggi jagaan > 0,3 meter.

2) Debit rancangan kala ulang 5 tahun

a) Pada P.21, P.28, P.29, P.30, dan P.34 air meluap pada tanggul sebelah kiri dan kanan karena memiliki elevasi banjir yang lebih tinggi dari pada elevasi tanggul kiri dan kanan.

b) Pada P.22, P.23, P.24, P.25, P.25, P.32, dan P.33 air meluap pada tanggul sebelah kanan karena memiliki elevasi banjir yang lebih tinggi dari pada elevasi tanggul kanan.

c) Pada P.27 air meluap pada tanggul sebelah kiri karena memiliki elevasi banjir yang lebih tinggi dari pada elevasi tanggul kiri.

d) Pada P.16, P.17, P.18, P.19, P.20, P.21, P.22, P.23, P.24, P.25, P.26, P.27, P.28, P.29, P.30, P.33, dan P.34 tidak memenuhi syarat tinggi jagaan pada tanggul sebelah kiri dan kanan karena memiliki tinggi jagaan $<0,3$ meter.

e) Pada P.32 tidak memenuhi syarat tinggi jagaan pada tanggul sebelah kanan karena memiliki tinggi jagaan $<0,3$ meter.

f) Selain penampang yang telah disebutkan pada point $\mathrm{a}, \mathrm{b}, \mathrm{c}, \mathrm{d}$, dan e, memiliki elevasi tanggul yang lebih tinggi dari pada elevasi banjir kala ulang 2 dan 5 tahun sehingga air tidak meluap. Selain itu, telah memenuhi syarat tinggi jagaan > 0,3 meter.

\section{E. Analisis Kinerja Operasi dan Pemeliharaan}

1) Uji Kualitas Data

a) Uji Validasi

Tabel Hasil Uji Validasi

\begin{tabular}{|c|c|c|c|c|}
\hline Kode & V ariabel/Indikaor Variabel & $R_{\text {tabel }}$ & $R_{\text {hinng }}$ & Ket \\
\hline $\mathrm{X} 1$ & Aspek Pelayanan Operasi & & & \\
\hline $\mathrm{X} 1.1$ & Bangunan pintu air & 0,388 & 0,623 & Valid \\
\hline $\mathrm{X} 1.2$ & Bangunan pengendali barjir atau pom pa air & 0,388 & 0,730 & Valid \\
\hline $\mathrm{X} 1.3$ & Petugas pem antau oper asi saluran drainase & 0,388 & 0,661 & Valid \\
\hline $\mathrm{X} 1.4$ & Petugas pemantau pada bangunan pintu air & 0,388 & 0,689 & Valid \\
\hline $\mathrm{X} 1.5$ & $\begin{array}{l}\text { Petugas pemantau pada bangunan pengendali } \\
\text { banjir }\end{array}$ & 0,388 & 0,632 & Valic \\
\hline $\mathrm{X} 1.6$ & Trashrack pada setiap inlet dan outlet saluran & 0,388 & 0,441 & Valia \\
\hline $\mathrm{X} 1.7$ & Jalan inspeksi & 0,388 & 0,715 & Valid \\
\hline $\mathrm{X} 1.8$ & Arsip data & 0,388 & 0,601 & Valial \\
\hline $\mathrm{X} 2$ & Aspek Pemeliharaan & & & \\
\hline $\mathrm{X} 2.1$ & Pem eliharaan pada bangunan saluran & 0,388 & 0,750 & Valial \\
\hline $\mathrm{X} 2.2$ & $\begin{array}{l}\text { Pemeliharaan pada bangunan penungang dan } \\
\text { pengendali banjir }\end{array}$ & 0,388 & 0,425 & Valid \\
\hline $\mathrm{X} 2.3$ & Pemeliharaan rutin & 0,388 & 0,458 & Valial \\
\hline $\mathrm{X} 2.4$ & Pem eliharaan berkala & 0,388 & 0,494 & Valia \\
\hline $\mathrm{X} 2.5$ & Pem eliharaan khusus atau rehabilitasi & 0,388 & 0,607 & Valial \\
\hline $\mathrm{X} 2.6$ & $\begin{array}{l}\text { Peralatan untuk pemeliharaan bangunan } \\
\text { saluran }\end{array}$ & 0,388 & 0,753 & Valid \\
\hline $\mathrm{X} 2.7$ & Sosialisasi kepada masyarakat & 0,388 & 0,429 & Valid \\
\hline $\mathrm{X} 3$ & Aspek Kondisi Lingkungan & & & \\
\hline $\mathrm{X} 3.1$ & Daerah resapan air atau ruang terbuka hijau & 0,388 & 0,678 & Valial \\
\hline $\mathrm{X} 3.2$ & Pemukim an dan tata guna lahan tertata baik & 0,388 & 0,762 & Valial \\
\hline $\mathrm{X} 3.3$ & Penyaringan air limbah & 0,388 & 0,836 & Valid \\
\hline $\mathrm{X} 3.4$ & $\begin{array}{l}\text { Tidak m embuang sampah rumah tangga } \\
\text { langsung ke saluran }\end{array}$ & 0,388 & 0,456 & Valid \\
\hline $\mathrm{X} 3.5$ & Bak kontrol pada setiap rumah tangga & 0,388 & 0,536 & Valial \\
\hline $\mathrm{X} 3.6$ & $\begin{array}{l}\text { Tepi kanan dan kiri saluran terbebas dari } \\
\text { bangunan liar }\end{array}$ & 0,388 & 0,399 & Valic \\
\hline $\mathrm{X} 4$ & Aspek Fisik Bangunan & & & \\
\hline $\mathrm{X} 4.1$ & $\begin{array}{l}\text { Inlet saluran bersih dari sampah dan } \\
\text { sedimetasi }\end{array}$ & 0,388 & 0,512 & Valic \\
\hline $\mathrm{X} 4.2$ & $\begin{array}{l}\text { Tidak terjadi pendangkalan saluran akibat } \\
\text { sedimentasi }\end{array}$ & 0,388 & 0,507 & Valial \\
\hline $\mathrm{X} 4.3$ & $\begin{array}{l}\text { Tidak terdapat banyak tumpukan sampah } \\
\text { pada permukaan saluran }\end{array}$ & 0,388 & 0,608 & Valial \\
\hline $\mathrm{X} 4.4$ & $\begin{array}{l}\text { Tidak terdapat gulm a atau tanaman enceng } \\
\text { gondok pada permukaan saluran }\end{array}$ & 0,388 & 0,538 & Valia \\
\hline $\mathrm{X} 4.5$ & $\begin{array}{l}\text { Struktur dinding saluran dalam kondisi baik } \\
\text { dan tidak ter dapat retakan atau runtuhan }\end{array}$ & 0,388 & 0,444 & Valic \\
\hline $\mathrm{X} 4.6$ & $\begin{array}{l}\text { Saluran sekunder dan tersier terkoneksi baik } \\
\text { denga saluran primer }\end{array}$ & 0,388 & 0,554 & Valia \\
\hline $\mathrm{X} 4.7$ & $\begin{array}{l}\text { Terdapat tangggul atau parapet di separiang } \\
\text { saluran drainase terutama pada daerah hilir }\end{array}$ & 0,388 & 0,495 & Valia \\
\hline $\mathrm{X} 4.8$ & Railing di sepanjang bibir drainase & 0,388 & 0,506 & Valied \\
\hline $\mathrm{X} 5$ & Aspek Partisipasi Instansi Terkait & & & \\
\hline $\mathrm{X} 5.1$ & $\begin{array}{l}\text { Struktur kelem bagaan yang mengurusi } \\
\text { penyelenggaraan OP drainase }\end{array}$ & 0,388 & 0,735 & Valia \\
\hline $\mathrm{X} 5.2$ & $\begin{array}{l}\text { Peraturan instansi terkait penyelenggaraan } \\
\text { OP saluran drainase primer }\end{array}$ & 0,388 & 0,807 & Valia \\
\hline $\mathrm{X} 5.3$ & $\begin{array}{l}\text { Standar operasional prosedur } \\
\text { pelaksanaan OP saluran drainase }\end{array}$ & 0,388 & 0,773 & Valid \\
\hline $\mathrm{X} 6$ & Aspek Peran Serta Masyarakat & & & \\
\hline $\mathrm{X} 6.1$ & $\begin{array}{lccc}\begin{array}{l}\text { Masyarakat ikut serta dalam kegiatan } \\
\text { sosialisasi terkait pem eliharaan saluran } \\
\text { drainase }\end{array} & & \\
\end{array}$ & 0,388 & 0,560 & Valiel \\
\hline $\mathrm{X} 6.2$ & $\begin{array}{l}\text { Masyarakat aktif dalam pemeliharaan saluran } \\
\text { drainase dengan idak membuang sampah } \\
\text { kedalam saluran }\end{array}$ & 0,388 & 0,767 & Valia \\
\hline $\mathrm{x} 6.3$ & $\begin{array}{l}\text { Masyarakt aktif dalam pelaksanaan } \\
\text { pengoperasian saluran dengan tidak } \\
\text { mengalih-fungsikan tepi-tepi saluran }\end{array}$ & 0,388 & 0,732 & Valiel \\
\hline X6.4 & $\begin{array}{l}\text { Masyarakat aktif dalam kegiatan gotong } \\
\text { royong / bersih-bersih saluran }\end{array}$ & 0,388 & 0,629 & Valial \\
\hline $\mathrm{X} 6.5$ & $\begin{array}{l}\text { Masyarakat aktif dalam memberi laporan } \\
\text { genangan air }\end{array}$ & 0,388 & 0,580 & Valial \\
\hline
\end{tabular}


b) Uji Reliabilitas

Tabel Hasil Uji Reliabilitas

\begin{tabular}{clccc}
\hline Kode & \multicolumn{1}{c}{ Variabel } & $\begin{array}{c}\text { Nilai Alpha } \\
\text { Analisa }\end{array}$ & $\begin{array}{c}\text { Cronbach' } \\
\text { s Alpha }\end{array}$ & Ket \\
\hline $\mathrm{X} 1$ & Aspek Pelayanan Operasi & 0,600 & 0,783 & Reliabel \\
\hline $\mathrm{X} 2$ & Aspek Pemeliharaan & 0,600 & 0,623 & Reliabel \\
\hline $\mathrm{X} 3$ & Aspek Kondisi Lingkungan & 0,600 & 0,608 & Reliabel \\
\hline $\mathrm{X} 4$ & Aspek Fisik Bangunan & 0,600 & 0,603 & Reliabel \\
\hline $\mathrm{X} 5$ & $\begin{array}{l}\text { Aspek Partisipasi Instansi } \\
\text { Terkait }\end{array}$ & 0,600 & 0,662 & Reliabel \\
\hline $\mathrm{X} 6$ & $\begin{array}{l}\text { Aspek Peran Serta } \\
\text { Masyarakat }\end{array}$ & 0,600 & 0,608 & Reliabel \\
\hline Sumber : Hasil Olah Data : 2020 & & & &
\end{tabular}

2) Uji Asumsi Klasik

a) Uji Multikolinearitas

Tabel Hasil Uji Multikolinearitas

\begin{tabular}{clcc}
\hline Kode & \multicolumn{1}{c}{ Variabel } & Tolerance & VIF \\
\hline $\mathrm{X} 1$ & Aspek Pelayanan Operasi & 0,930 & 1,075 \\
\hline $\mathrm{X} 2$ & Aspek Pemelihara an & 0,752 & 1,330 \\
\hline $\mathrm{X} 3$ & Aspek Kondisi Lingkungan & 0,813 & 1,231 \\
\hline $\mathrm{X} 4$ & Aspek Fisik B angunan & 0,903 & 1,108 \\
\hline $\mathrm{X} 5$ & Aspek Partisipasi Instansi Terkait & 0,967 & 1,034 \\
\hline $\mathrm{X} 6$ & Aspek Peran Serta Masyarakat & 0,793 & 1,262 \\
\hline Sumber : Hasil Olah Data : 2020 & &
\end{tabular}

b) Uji Heterokedastisitas

Tabel Hasil Uji Heterokedastisitas

\begin{tabular}{clcc}
\hline Kode & \multicolumn{1}{c}{ Variabel } & Batas Sig. & Nilai Sig. \\
\hline $\mathrm{X} 1$ & Aspek Pelayanan Operasi & 0,05 & 0,596 \\
\hline $\mathrm{X} 2$ & Aspek Pemeliharaan & 0,05 & 0,725 \\
\hline $\mathrm{X} 3$ & Aspek Kondisi Lingkungan & 0,05 & 0,481 \\
\hline $\mathrm{X} 4$ & Aspek Fisik Bangunan & 0,05 & 0,715 \\
\hline $\mathrm{X} 5$ & Aspek Partisipasi Instansi Terkait & 0,05 & 0,168 \\
\hline $\mathrm{X} 6$ & Aspek Peran Serta Masyarakat & 0,05 & 0,745 \\
\hline
\end{tabular}

c) Uji Normalitas

Hasil uji normalitas dengan metode grafik P-P plot of regression standardized residual dapat dilihat pada gambar berikut.

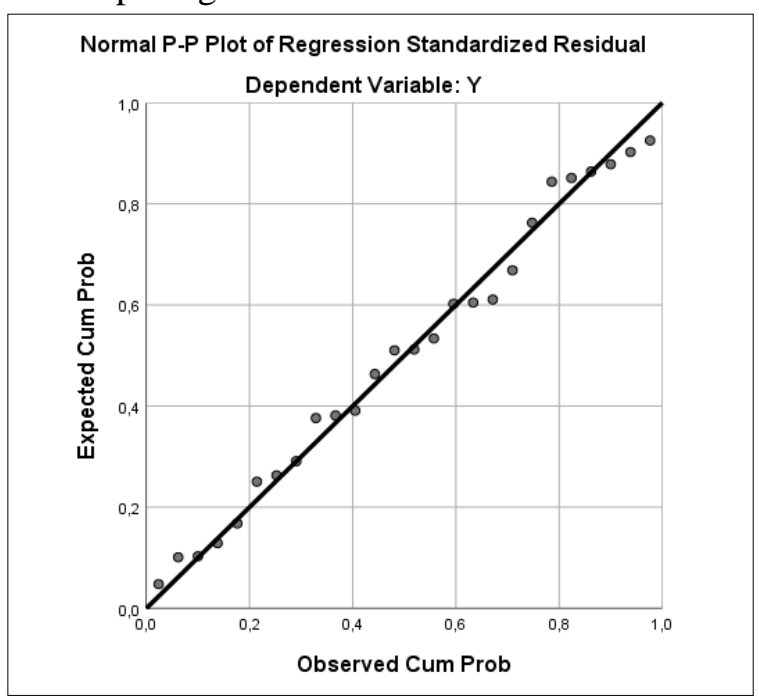

Gambar Grafik P-P plot of regression standardized residual
3) Uji Hipotesis

a) Uji Persamaan Linear Berganda

Tabel Hasil Uji Regresi Linear Berganda

\begin{tabular}{clcc}
\hline \multirow{2}{*}{ Kode } & \multicolumn{2}{c}{ Variabel } & \multicolumn{2}{c}{ Unstandardized Coefficient } \\
\cline { 3 - 4 } & & $-2,647$ & Sd. Error \\
\hline Constant & & 0,046 & 0,907 \\
\hline $\mathrm{X} 1$ & Aspek Pelayanan Operasi & 0,096 & 0,047 \\
\hline $\mathrm{X} 2$ & Aspek Pemeliharaan & 0,005 & 0,052 \\
\hline $\mathrm{X} 3$ & Aspek Kondisi Lingkungan & 0,095 & 0,037 \\
\hline $\mathrm{X} 4$ & Aspek Fisik Bangunan & $-0,029$ & 0,055 \\
\hline $\mathrm{X} 5$ & Aspek Partisipasi Instansi Terkait & 0,050 & 0,074 \\
\hline $\mathrm{X} 6$ & Aspek Peran Serta Masyarakat & &
\end{tabular}

$$
\begin{aligned}
Y= & -2,647+0,046 \mathrm{X} 1+0,096 \mathrm{X} 2+0,005 \mathrm{X3}+ \\
& 0,095 \mathrm{X} 4-0,029 \mathrm{X} 5+0,050 \mathrm{X6}
\end{aligned}
$$

Keterangan :

$\mathrm{Y}=$ Kapasitas Drainase

$\mathrm{X} 1=$ Aspek Pelayanan Operasi

$\mathrm{X} 2=$ Aspek Pemeliharaan

$\mathrm{X} 3=$ Aspek Kondisi Lingkungan

$\mathrm{X} 4=$ Aspek Fisik Bangunan

X5 = Aspek Partisipasi Instansi Terkait

X6 = Aspek Peran Serta Masyarakat

b) Uji t Parsial

Tabel Hasil Uji t Parsial

\begin{tabular}{clrrc}
\hline Kode & \multicolumn{1}{c}{ V ariabel } & $\mathrm{t}_{\text {abel }}$ & thinng & Sig. \\
\hline Constant & & & $-1,388$ & 0,181 \\
\hline $\mathrm{X} 1$ & A spek Pelayanan Oper asi & 2,093 & 1,573 & 0,132 \\
\hline $\mathrm{X} 2$ & A spek Pemeliharaan & 2,093 & 2,068 & 0,052 \\
\hline $\mathrm{X} 3$ & A spek Kondisi Lingkungan & 2,093 & 0,100 & 0,921 \\
\hline $\mathrm{X} 4$ & A spek Fisik B angunan & 2,093 & 2,544 & 0,020 \\
\hline $\mathrm{X} 5$ & A spek Partisipasi Instansi Terkait & 2,093 & $-0,521$ & 0,608 \\
\hline $\mathrm{X} 6$ & A spek Peran Serta Masyarakat & 2,093 & 0,669 & 0,512 \\
\hline Sumber : Hasil Olah Data : 2020 & & &
\end{tabular}

c) Uji F Simultan

\begin{tabular}{|c|c|c|c|c|c|}
\hline \multicolumn{6}{|c|}{ ANOVA $^{a}$} \\
\hline Model & $\begin{array}{l}\text { Sum of } \\
\text { Squares }\end{array}$ & df & $\begin{array}{l}\text { Mean } \\
\text { Square }\end{array}$ & $\mathrm{F}$ & Sig. \\
\hline 1 Regression & 3,235 & 6 &, 539 & 2,749 &, $043^{b}$ \\
\hline Residual & 3,726 & 19 & , 196 & & \\
\hline Total & 6,962 & 25 & & & \\
\hline \multicolumn{6}{|c|}{$\begin{array}{l}\text { a. Dependent Variable: Y } \\
\text { b. Predictors (Constant), Total X6, Total X5, Total X1, Total X3, Total X4, Total X2 }\end{array}$} \\
\hline
\end{tabular}

Tabel Hasil Uji F Simultan

Berdasarkan tabel diatas menunjukkan nilai signifikansi sebesar $0,043<0,05$ dan nilai $\mathrm{F}_{\text {hitung }}$ sebesar 2,749 $>2,60$ menunjukkan bahwa semua variabel independen (variabel $\mathrm{X}$ ) yakni aspek pelayanan operasi (X1), aspek pemeliharaan (X2), aspek kondisi lingkungan (X3), aspek fisik bangunan (X4), aspek partifipasi instansi terkait (X5) dan aspek peran serta masyarakat (X6) berpengaruh signifikan 
secara simultan atau bersama-sama terhadap variabel dependen (variabel Y) yakni kapasitas drainase.

4) Aspek-aspek yang Berpengaruh Dominan

Dari kelima variabel yang memiliki nilai koefisien positif pada uji persamaan linear berganda, dapat ditentukan variabel yang dominan dengan melihat variabel yang berpengaruh secara signifikan pada hasil uji t parsial, dimana hasil uji tersebut menunjukkan variabel aspek fisik bangunan berpengaruh secara signifikan terhadap variabel dependent (Y). Sehingga variabel yang berpengaruh secara dominan dalam peningkatan kapasitas drainase yaitu variabel aspek fisik bangunan.

5) Upaya dalam Meningkatkan Kapasitas Drainase Sinrijala

Kondisi eksisting drainase Sinrijala saat ini memang memiliki beberapa permasalahan terutama pada fisik bangunannya. Kelandaian dasar saluran dan berkurangnya daya tampung saluran disebabkan oleh sedimentasi. Oleh karena itu dibutuhkan penanganan berupa kegiatan normalisasi berupa pengerukan dan penambahan tanggul.

Untuk itu dilakukan simulasi pertama yaitu melakukan running kedua menggunakan aplikasi HEC-RAS 4.1.0 untuk analisis kapasitas dengan menambah kedalaman penampang saluran.

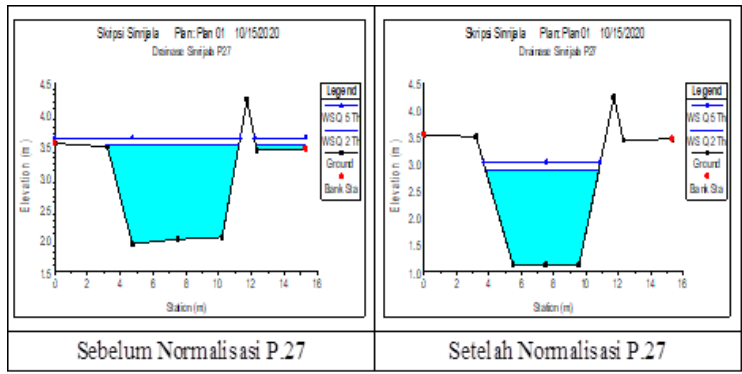

Gambar Perbandingan Kondisi Profil pada Patok P.30 Simulasi 1

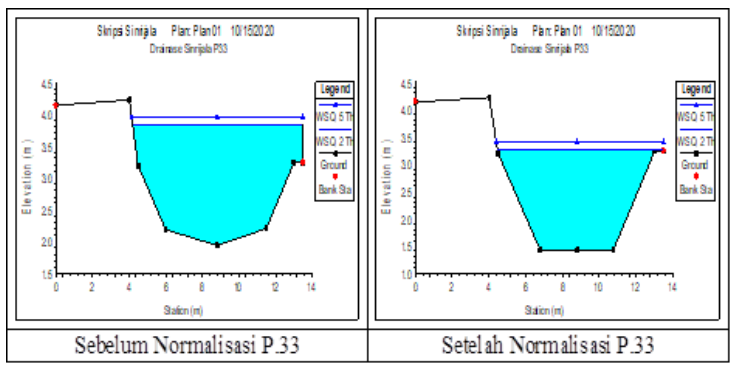

Gambar Perbandingan Kondisi Profil pada Patok P.33 Simulasi 1
Setelah dilakukan simulasi pertama, ternyata masih terdapat beberapa penampang yang belum memenuhi syarat kapasitas tampung, sehingga dilakukan simulasi kedua yaitu penambahan tanggul kanan dan kiri pada penampang yang belum memenuhi syarat.

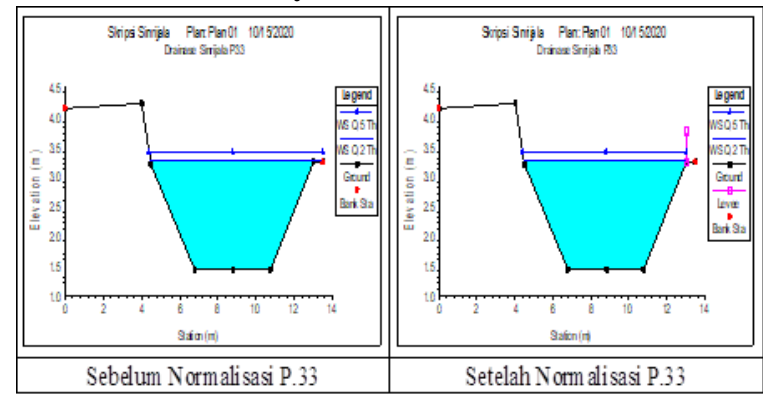

Hasil simulasi kedua menunjukkan elevasi tanggul lebih tinggi dari pada muka air banjir di semua penampang (P.0 - P.34). Selain itu, penampang juga telah memenuhi syarat tinggi jagaan. Sehingga kegiatan normalisasi berupa pengerukan dan penambahan tanggul telah menjadikan penampang mampu menampung debit banjir kala ulang 2 tahun dan 5 tahun.

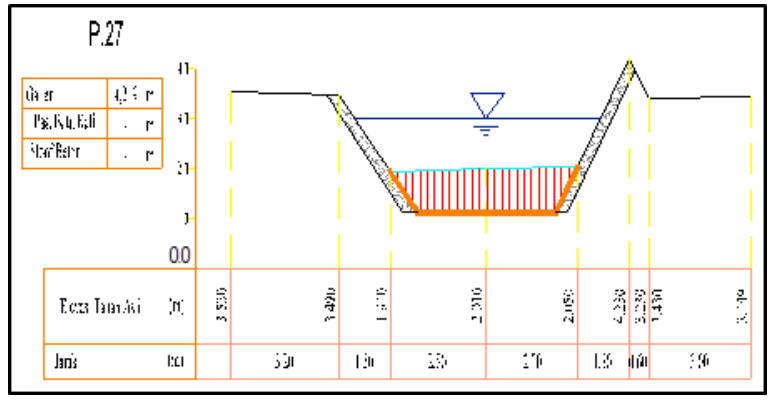

Gambar Cross Section P.27 untuk Normalisasi

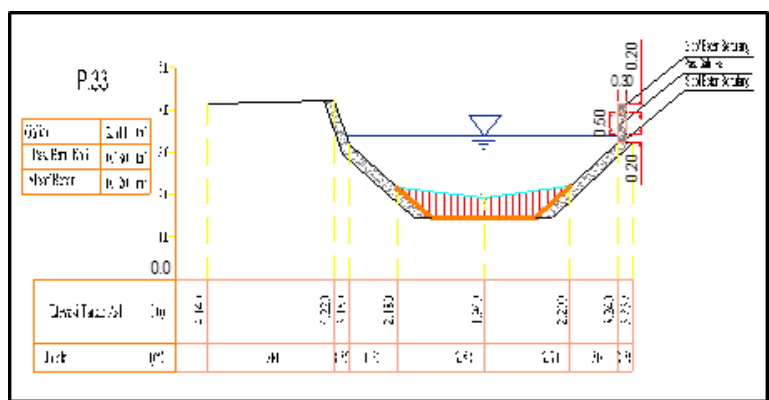

Gambar Cross Section P.33 untuk Normalisasi

6) Rekomendasi Pelaksanaan Operasi dan Pemeliharaan Drainase Sinrijala

Untuk menjaga kinerja fisik bangunan drainase, selain melakukan normalisasi berupa pengerukan sedimentasi dan penambahan tanggul, perlu pula dilakukan penanganan pada aspek 
yang lain yang berpegaruh secara simultan dalam upaya peningkatan kapasitas drainase Sinrijala. Berdasarkan hasil uji $\mathrm{F}$ simultan, menunjukkan bahwa keenam variabel berpengaruh secara simultan. Sehingga peningkatan kinerja pada semua variabel perlu dilakukan. Berikut adalah urutan prioritas untuk peningkatan kapasitas drainase Sinrijala beserta rekomendasi penanganannya.

\section{a) Pengerukan Sedimentasi}

Tabel Rekomendasi Kegiatan Pengerukan Sedimentasi

\begin{tabular}{|c|c|c|c|}
\hline Uraian Kegiatan & $\begin{array}{l}\text { Kondisi } \\
\text { Faktual }\end{array}$ & $\begin{array}{l}\text { Kebutuhan } \\
\text { Pengelolaan }\end{array}$ & Konsep Pengel olaan \\
\hline \multirow{6}{*}{$\begin{array}{l}\text { Peng galian penge } \\
\text { rukan sedimen } \\
\text { dan sampah di } \\
\text { dasar kanal }\end{array}$} & \multirow{6}{*}{$\begin{array}{l}\text { Banyakniya } \\
\text { sedimen } \\
\text { can sampah } \\
\text { yang } \\
\text { terdekompo } \\
\text { sisi di dasar } \\
\text { kanal } \\
\text { sehingga } \\
\text { mengurangi } \\
\text { kapasitas } \\
\text { kanal. }\end{array}$} & \multirow{6}{*}{ 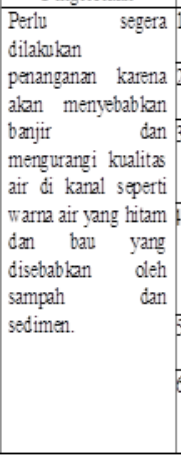 } & $\begin{array}{l}\text { Pengerukan sampah dan sedimen di } \\
\text { dasar kanal }\end{array}$ \\
\hline & & & $\begin{array}{l}\text { 2) Pengerukan diutamakan pada titik yang } \\
\text { sangat rentan yakni pada daerah hulu }\end{array}$ \\
\hline & & & $\begin{array}{l}\text { Pengangkutan hasil galian sampah dan } \\
\text { sedimen ke TPA atav tempat } \\
\text { pembuangan akhir }\end{array}$ \\
\hline & & & $\begin{array}{l}\text { Operasi nutin pembersihan sampah di } \\
\text { kanal untuk mencegah dekomposisi } \\
\text { sampah di dasar kanal oleh petugas } \\
\text { OP kanal }\end{array}$ \\
\hline & & & $\begin{array}{l}\text { 5) Pemberian sang si bagi warga industif } \\
\text { yang membuang sampah ke kanal. }\end{array}$ \\
\hline & & & $\begin{array}{l}\text { 5) Perlunya pembuatan bangunan } \\
\text { penangkap pasir'sedimen atau sebelum } \\
\text { air masuk ke kanal. }\end{array}$ \\
\hline
\end{tabular}

b) Penambahan Tanggul

Tabel Rekomendasi Kegaiatan Penambahan Tanggul

\begin{tabular}{|c|c|c|c|}
\hline $\begin{array}{c}\text { Uraian } \\
\text { Kegiatan }\end{array}$ & Kondisi Faktual & Kebutuhan Pengelolaan & Konsep Peng el olaan \\
\hline $\begin{array}{l}\text { Penambahan } \\
\text { tanggul }\end{array}$ & 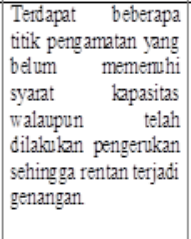 & $\begin{array}{l}\text { Peilu segera dilakukan } \\
\text { penambahan tanggul pada } \\
\text { titik-titik yang rentan } \\
\text { Untuk titik-titik lain } \\
\text { penambahan r tanggul } \\
\text { belum menjadi prioritas } \\
\text { utama, namnun menjadi } \\
\text { perencanaan } \\
\text { panjang. }\end{array}$ & $\begin{array}{l}\text { 1) Peilu segera dilakukan } \\
\text { penambahan tanggul pada } \\
\text { titik-titik yang rentan } \\
\text { (P.29, P. } 30, \text { P. } 33 \text {, daan } \\
\text { P.34). } \\
\text { 2) Tanggul direncanakan } \\
\text { memakai pasangan batu } \\
\text { dengan tinggi } 0,3 \mathrm{~m} \text {. }\end{array}$ \\
\hline
\end{tabular}

c) Dinding Saluran

Tabel Rekomendasi Kegiatan Perbaikan Dinding Saluran

\begin{tabular}{|c|c|c|c|}
\hline $\begin{array}{l}\text { Uraian } \\
\text { Kegiatan }\end{array}$ & Kondisi Faktual & Kebutuhan Pengelolaan & Konsep Pengelolaan \\
\hline $\begin{array}{l}\text { Perbaikan } \\
\text { Dinding } \\
\text { Salurant }\end{array}$ & $\begin{array}{l}\text { Adanya } \\
\text { kerusakan ringan } \\
\text { sampai berat } \\
\text { berupa retakan } \\
\text { dan bocor pada } \\
\text { dinding saluran. }\end{array}$ & $\begin{array}{l}\text { Perbaikan dinding saluran yang } \\
\text { mengalami kerusakan berat menjadi } \\
\text { prioritas utama untuk menghindari } \\
\text { kerusakan yang lebih fatal. Sementara } \\
\text { untuk kerusakan ringan belum menjadi } \\
\text { prioritas utama melainkan jangka. } \\
\text { menengah dalam OP. }\end{array}$ & $\begin{array}{l}\text { Retak-retak atau } \\
\text { kebocoran tanggul perlu } \\
\text { segera diatasi terutama } \\
\text { pada tanggul dengan } \\
\text { pasangan menghindari } \\
\text { kerusakan yang lebih } \\
\text { fatal. }\end{array}$ \\
\hline
\end{tabular}

d) Outlet Saluran

Tabel Rekomendasi Penanganan pada Outlet Saluran

\begin{tabular}{|c|c|c|c|}
\hline $\begin{array}{l}\text { Uraian } \\
\text { Kegiatan }\end{array}$ & Kondisi Faktual & $\begin{array}{l}\text { Kebutuhan } \\
\text { Pengelol aan }\end{array}$ & Konsep Pengelolaan \\
\hline \multirow[t]{2}{*}{$\begin{array}{l}\text { utlet salur } \\
\text { 1 yang } \\
\text { lasuk ke } \\
\text { anal }\end{array}$} & $\begin{array}{l}\text { 1. Sebartyak } 63 \text { outlet dari } \\
\text { rumah warga atau industri } \\
\text { yang langsung masuk ke } \\
\text { kanal. }\end{array}$ & \multirow{2}{*}{$\begin{array}{l}\text { Penertiban saluran } \\
\text { atau outlet dari rumah } \\
\text { warga dan industri } \\
\text { mendesak dilakukan } \\
\text { guna menjaga kualitas } \\
\text { air dan mengurangi } \\
\text { sampah masuk ke } \\
\text { kanal. }\end{array}$} & $\begin{array}{l}\text { 1) Penertibkan } \\
\text { salurani oulet dari } \\
\text { rumah warga industri } \\
\text { yang langsung masuk } \\
\text { ke kanal }\end{array}$ \\
\hline & $\begin{array}{l}\text { 2. Saluran atav outlet tersebut } \\
\text { membuang langsung } \\
\text { limbahisampah dari rumah } \\
\text { tangga dan industri ke kanal } \\
\text { tanpa melalui pengolahan } \\
\text { terlebih dahulu. }\end{array}$ & & $\begin{array}{l}\text { 2) Memperbanyak } \\
\text { jumlah } \mathbb{P A L} \text { di sekitar } \\
\text { kanal. }\end{array}$ \\
\hline
\end{tabular}

e) Pemasangan Pompa Banjir

Tabel Rekomendasi Pemasangan Pompa Banjir

\begin{tabular}{|c|c|c|c|}
\hline $\begin{array}{c}\text { Uraian } \\
\text { Kegiatan }\end{array}$ & Kondisi Faltual & Kebutuhan Pengel daan & Konsep Pengelolaan \\
\hline $\begin{array}{l}\text { Pemasangan } \\
\text { pompabanjir }\end{array}$ & $\begin{array}{l}\text { Kondisi beberapa penampang } \\
\text { saluran yang sudah tidak } \\
\text { mampu menampung debit Q2 } \\
\text { dan Q5, hal tersebut akan } \\
\text { meningkatlan genangan pada } \\
\text { titik-titik dengan elevasi } \\
\text { rendah. }\end{array}$ & 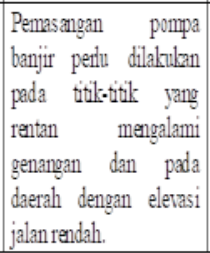 & $\begin{array}{ll}\text { Pemasangan } & \text { pompa } \\
\text { baniir } & \text { bersifit } \\
\text { pembangunan } & \\
\text { banusehingga } & \text { perlu } \\
\text { perencanaan } & \text { lebih } \\
\text { detail. } & \end{array}$ \\
\hline
\end{tabular}

f) Pemasangan Trash Rack

Tabel Rekomendasi Pemasangan Trash Rack

\begin{tabular}{|c|c|c|c|}
\hline $\begin{array}{c}\text { Uraian } \\
\text { Kegiatan } \\
\end{array}$ & Kondisi Faktual & $\begin{array}{l}\text { Kebutuhan } \\
\text { Pengelolaan } \\
\end{array}$ & Konsep Pengelolaan \\
\hline \multirow[t]{2}{*}{ Trashrack } & $\begin{array}{l}\text { Tidak terdapat trashrack } \\
\text { diruas kanal, baik yang } \\
\text { otomatis maupun mamual. }\end{array}$ & $\begin{array}{l}\text { Pemasangan trashrack } \\
\text { diruas kanal ini perlu } \\
\text { untuk dilakukan } \\
\text { disamping untuk } \\
\text { mengurangi beban } \\
\text { trasrack otomatis di } \\
\text { Kanal Pampang juga } \\
\text { kanal ini terkoneksi } \\
\text { dengan Kanal Jongaya } \\
\text { dan Pampang. }\end{array}$ & $\begin{array}{l}\text { 1) Pemas angan trashrack } \\
\text { mamual di Kanal Sinrijala }\end{array}$ \\
\hline & $\begin{array}{l}\text { Semua saluran sekunder } \\
\text { tersier yang masuk ke } \\
\text { kanal tidak dilengkapi } \\
\text { dengan trashrack sehingga } \\
\text { sampah apapun yang } \\
\text { dibawa oleh air dari } \\
\text { saluran tersebut semuanya } \\
\text { masuk ke kanal. }\end{array}$ & $\begin{array}{l}\text { Pemasangan trashrack } \\
\text { di saluran sekunder } \\
\text { dan tersier perlu } \\
\text { dilakukan r guna } \\
\text { mengurangi volume } \\
\text { sampah yang masuk } \\
\text { ke kanal. }\end{array}$ & $\begin{array}{l}\text { Pemasangan trashrack diakhir } \\
\text { saluran sekunder atau tersier } \\
\text { sebelum masuk ke kanal. }\end{array}$ \\
\hline
\end{tabular}

g) Pemasangan Railing/Pengaman

Tabel Rekomendasi Pemasangan Railing/Pengaman

\begin{tabular}{|c|c|c|c|}
\hline $\begin{array}{l}\text { Uraian } \\
\text { Kegiatan }\end{array}$ & Kondisi Faktual & $\begin{array}{l}\text { Kebutuhan } \\
\text { Pengelolaan }\end{array}$ & Konsep Peng elolaan \\
\hline \multirow[t]{2}{*}{$\begin{array}{l}\text { Pengaman } \\
\text { Railing }\end{array}$} & \multirow{2}{*}{\begin{tabular}{|l|l|} 
Beberapa ruas kanal \\
tidak memiliki \\
pengaman railing \\
dan nas lainnya \\
dalam kondisi nusak
\end{tabular}} & \multirow[t]{2}{*}{$\begin{array}{l}\text { Penanganan bersifat } \\
\text { jangka menengah- } \\
\text { panjang. }\end{array}$} & $\begin{array}{l}\text { 1) Pemas angan railing peng aman pada } \\
\text { ruas yang belum memiliki pengaman } \\
\text { terutama didaerah pemukiman }\end{array}$ \\
\hline & & & $\begin{array}{l}\text { 2) Jenis railing pengaman sebaiknya } \\
\text { menghindari bahan yang terbuat dari } \\
\text { besi atau baja. }\end{array}$ \\
\hline
\end{tabular}


h) Perbaikan Jalan Inspeksi

Tabel Rekomendasi Perbaikan Jalan Inspeksi

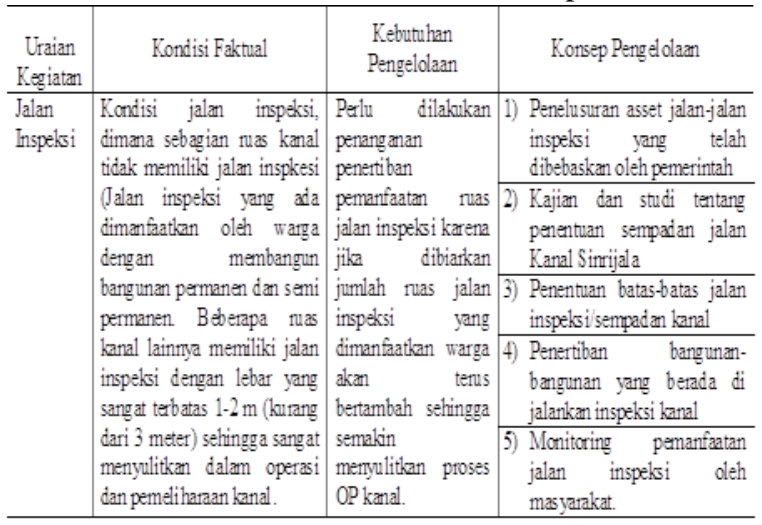

\section{Penutup}

\section{A. Kesimpulan}

Berdasarkan hasil penelitian yang dilakukan, maka diperoleh kesimpulan sebagai berikut :

1) Debit rencana yang dihasilkan pada drainase Sinrijala adalah Q2 $=8,798 \mathrm{~m}^{3} /$ detik dan Q5 = $10,304 \mathrm{~m}^{3} /$ detik. Dari hasil simulasi eksisting dengan Q 2 tahun diperoleh P.16, P.17, P.18, P.19, P.20, P.21, P.22, P.23, P.24, P.25, P.26, P.27, P.28, P.29, P.30, P.32, P.33, dan P.34 tidak memenuhi syarat kapasitas saluran, sementara untuk Q 5 tahun tidak memenuhi syarat kapasitas saluran pada P.16, P.17, P.18, P.19, P.20, P.21, P.22, P.23, P.24, P.25, P.26, P.27, P.28, P.28, P.29, P.30 P.32, P.33, dan P.34.

2) Variabel Fisik Bangunan (X4) merupakan faktor yang berpengaruh dominan dalam kinerja peningkatan kapasitas Drainase Sinrijala, upaya dalam mengatasi permasalahan banjir dan genangan adalah melakukan normalisasi berupa pengerukan, penambahan tanggul dan perbaikan dinding saluran yang mengalami kerusakan berat menjadi prioritas utama untuk meningkatkan fisik bangunan drainase Sinrijala. Sementara itu, perbaikan dinding saluran untuk kerusakan ringan, pemeliharaan outlet saluran, pemasangan trashrack, pemasangan pompa banjir dan pemasangan pengaman/railing perlu pula dilakukan dalam jangka menengah dan panjang untuk meningkatkan kinerj kapasitas drainase Sinrijala.

\section{B. Saran}

Adapun saran yang berkaitan dengan penelitian ini sebagai berikut :

1) Diharapkan penelitian ini dapat menjadi masukan- bagi pemerintah dan instansi untuk kegiatan operasi dan pemeliharaan dalam upaya peningkatan kapasitas drainase Sinrijala.

2) Dalam menganalisis pemodelan kinerja sebaiknya memperhitungkan pengaruh antar variabel $\mathrm{X}$.

3) Diperlukan kajian lebih khusus dalam perencanaan teknis kegiatan operasi dan pemeliharaan, khususnya perencanaan trash rack dan pompa banjir.

\section{Daftar Pustaka}

[1] Andana, Bayu ; Arisanty, Deasy dan Adyatma Sidharta. 2016.Evaluas Daya Tampung Sistem Drainase di Kecamatan Banjarmasin Selatan.Banjarmasin : Universitas Lambung Mangkurat.

[2] Balai Besar Wilayah Sungai Pompengan - Jeneberang.Peta Master Plan Drainase Kota Makassar.Makassar.

[3] Ghozali, Imam. 22011. Aplikasi Analisis Multivariate dengan Program IBM SPSS 19. Semarang : Badan Penerbit Undip.

[4] Kelinger, F. N. dan Lee, H. B. 2000.Foundation of Behavioral Research (Fourth Edition).USA : Holt, Reinnar \& Winston, Inc.

[5] Kodoatie, R. J. dan Sjarief, R. 2008.Pengelolaan Sumber Daya Air Terpadu. Andi Offset. Jakarta.

[6] Lestari Jufrian, Mega dan Ardiansyah. 2019.Analisis Kinerja Drainase Jalan Pacerakang Kota Makassar.Makassar Politeknik Negeri Ujung Pandang.

[7] Menteri Pekerjaan Umum Republik Indonesia. 2014. Peraturan Menteri Pekerjaan Umum Republik Indonesia Nomor 12/PRT/M/2014 tentang Penyelenggaraan Sistem Drainase Perkotaan. Jakarta.

[8] Mursitaningsih.2009.Analisis Kinerja Saluran Drainase D Daerah Tangkapan Air Hujan Sepanjang Kali Pepe Kota Surakarta.Bandung : Institut Teknolofi Bandung.

[9] Priyo Hutomo, Fajar dan Firmansyah, Rheza. 2016.Analisis Hidrologi dan Kapasitas Sistem Drainase Kota Surakarta.Semarang : Universitas Negeri Semarang.

[10] Restiani, Esi dan Sabri, Fadillah. 2015.Analisis Kinerja Sistem Drainase Keluarahan Kutp Panji Kecamatan Belinyu. (Online), (https://www.neliti.com/publications/61267/analisis-kinerjasistem-drainase-kelurahan-kuto-panji-kecamatan-belinyu). Bangka Belitung : Universitas Bangka Belitung.

[11] Suhardjono. 1984.Drainase.Malang : Universitas Brawijaya.

[12] Sujarweni, V.Wiratna. 2014. SPSS untuk Penelitian. Yogyakarta : Pustaka Baru Press.

[13] Suripin.2004.Sistem Drainase Perkotaan yang Berkelanjutan Penerbit ANDI.Yogyakarta.

[14] Sitepu. 2019.Simulasi Morfologi Dasar Sungai Way Sekampung Menggunakan Software HEC-RAS.Lampung : Universitas Lampung.

[15] Trisno Saputro, Danang ; Ismoyo, M. Janu dan Hadi Wicaksono, Prima.Perencanaan Drainase Perkotaan di Kota Nanga Bulik Kabupaten Lamandau Provinsi Kalimantan Tengah.Malang : Universitas Brawijaya.

[16] Vigiyanto, Antok.Analisis Normalisasi Saluran Drainase Kecamatan Kota Di Kabupaten Tuban.Surabaya : Universitas Negeri Surabaya.

[17] Yuswar.2015. Analisis Pengelolaan dan Pemeliharaan Drainase Kota Banda Aceh Secara Terpadu, (Online), (https://etd.unsyiah.ac.id/baca/index.php?id=13486\&page=6). Banda Aceh : Universitas Syiah Kuala. 